\title{
Transition Metal(II) Complexes with Cefotaxime-Derived Schiff Base: Synthesis, Characterization, and Antimicrobial Studies
}

\author{
Aurora Reiss, ${ }^{1}$ Mariana Carmen Chifiriuc, ${ }^{2}$ Emilia Amzoiu, ${ }^{3}$ and Cezar Ionuţ Spînu1 \\ ${ }^{1}$ Department of Chemistry, Faculty of Mathematics and Natural Sciences, University of Craiova, 107I Calea Bucureşti, \\ 200478 Craiova, Romania \\ ${ }^{2}$ Department of Microbiology, Faculty of Biology, University of Bucharest, 1-4 Aleea Portocalelor, 60101 Bucharest, Romania \\ ${ }^{3}$ Faculty of Pharmacy, University of Medicine and Pharmacy of Craiova, 66, 1 May Street, 200638 Craiova, Romania
}

Correspondence should be addressed to Aurora Reiss; reissaurora@yahoo.com

Received 7 October 2013; Revised 23 December 2013; Accepted 27 December 2013; Published 12 February 2014

Academic Editor: Claudio Pettinari

Copyright (C) 2014 A. Reiss et al. This is an open access article distributed under the Creative Commons Attribution License, which permits unrestricted use, distribution, and reproduction in any medium, provided the original work is properly cited.

\begin{abstract}
New $\left[\mathrm{ML}_{2}\left(\mathrm{H}_{2} \mathrm{O}\right)_{2}\right]$ complexes, where $\mathrm{M}=\mathrm{Co}(\mathrm{II}), \mathrm{Ni}(\mathrm{II}), \mathrm{Cu}(\mathrm{II})$, and $\mathrm{Zn}(\mathrm{II})$ while $\mathrm{L}$ corresponds to the Schiff base ligand, were synthesized by condensation of cefotaxime with salicylaldehyde in situ in the presence of divalent metal salts in ethanolic medium. The complexes were characterized by elemental analyses, conductance, and magnetic measurements, as well as by IR and UVVis spectroscopy. The low values of the molar conductance indicate nonelectrolyte type of complexes. Based on spectral data and magnetic moments, an octahedral geometry may be proposed for $\mathrm{Co}(\mathrm{II}), \mathrm{Ni}(\mathrm{II})$, and $\mathrm{Zn}$ (II) complexes while a tetragonal geometry for $\mathrm{Cu}(\mathrm{II})$ complex. Molecular structure of the Schiff base ligand and its complexes were studied using programs dedicated to chemical modeling and quantomolecular calculation of chemical properties. All the synthesized complexes were tested for in vitro antibacterial activity against some pathogenic bacterial strains, namely Escherichia coli, Klebsiella pneumoniae, Pseudomonas aeruginosa, Bacillus subtilis, and Staphylococcus aureus. The MIC values shown by the complexes against these bacterial strains revealed that the metal complexes possess superior antibacterial activity than the Schiff base.
\end{abstract}

\section{Introduction}

Infectious diseases caused by bacteria remain a major worldwide health problem due to rapid development of resistance to the existing antimicrobial drugs. Considering the emergence of pathogenic bacteria multidrug resistant strains, the discovery of new antimicrobial compounds is highly important. Cephalosporins (also named $\beta$-lactams) are synthetic antibiotics active against Gram-negative and Gram-positive bacteria by inhibiting the synthesis of the peptidoglycan layer from the cell wall [1]. The antibiotics of this class have in their structure a $\beta$-lactam ring that helps the antibiotic to bind to the enzymes that synthesize the peptidoglycan layer and perturbs the process. The mechanism that makes bacteria resistant to $\beta$-lactams is due to the synthesis of $\beta$-lactamase enzymes that break the $\beta$-lactam ring and the antibiotic cannot bind to peptidoglycan layer [2].

The antibiotic cefotaxime is the third generation cephalosporins which possess increased activity against bacteria than the first and second generation cephalosporins. Many drugs possess better pharmacological properties when they are in the form of metal complexes. So, the literature presents many metal complexes of different cephalosporins and their biological activity [3-16], but only a few studies present metal complexes with Schiff base derived from cephalosporins [1722].

In this context, the aim of this study was to assess the antimicrobial activity of some newly synthesized compounds of transition metallic ions $\mathrm{Co}(\mathrm{II}), \mathrm{Ni}(\mathrm{II}), \mathrm{Cu}(\mathrm{II})$, and $\mathrm{Zn}$ (II) with the Schiff base derived from cefotaxime with salicylaldehyde.

\section{Experimental}

2.1. Materials. All the chemicals (E. Merk, Germany) were used without further purification. All metal salts used were chloride $\left(\mathrm{CuCl}_{2} \cdot 2 \mathrm{H}_{2} \mathrm{O}, \mathrm{NiCl}_{2} \cdot 6 \mathrm{H}_{2} \mathrm{O}, \mathrm{CoCl}_{2} \cdot 6 \mathrm{H}_{2} \mathrm{O}\right.$, or $\mathrm{ZnCl}_{2} \cdot 2 \mathrm{H}_{2} \mathrm{O}$ ). Solvents used were of analytical grade. 
2.2. Synthesis of the Schiff Base. A solution of cefotaxime sodium ( $1 \mathrm{mmol}$ in $40 \mathrm{~mL}$ methanol) was added drop-wise, under stirring to a solution of salicylaldehyde $(1 \mathrm{mmol}$ in $10 \mathrm{~mL}$ methanol). A solution of $0.1 \mathrm{M} \mathrm{NaOH}$ was added to adjust the $\mathrm{pH}$ at 7-8 and the reaction mixture was refluxed for $3 \mathrm{~h}$. The resulting product was filtered off, washed with distilled water and methanol, and dried under vacuum. Recrystallization from a mixture of ethanol-propanol $(50: 50)$ gave the Schiff base. M.p. $150-153^{\circ} \mathrm{C}$ (found: C, 47.35; H, 3.41; N, $12.00 \%$ Calcd. for $\mathrm{C}_{23} \mathrm{H}_{20} \mathrm{~S}_{2} \mathrm{O}_{8} \mathrm{~N}_{5} \mathrm{Na}: \mathrm{C}, 47.50 ; \mathrm{H}, 3.44 ; \mathrm{N}$, $12.04 \%)$.

2.3. Syntheses of the Metal Complexes. The metal complexes were prepared following the same method. The Schiff base was prepared in situ from the precursors as follows: a solution of cefotaxime sodium ( $2 \mathrm{mmol}$ in $40 \mathrm{~mL}$ ethanol) was added to a solution of salicylaldehyde $(2 \mathrm{mmol}$ in $10 \mathrm{~mL}$ ethanol). The resulting mixture was refluxed for $3 \mathrm{~h}$ and then a methanolic solution $0.1 \mathrm{M}$ of $\mathrm{NaOH}$ was added. In the next step, the metal salts ( $1 \mathrm{mmol}$ in $15 \mathrm{~mL}$ ethanol) were added to the ligand solution under continuous stirring when the complex was precipitate. The obtained colored product was separated by filtration, washed with distilled water and methanol, and dried under vacuum. Recrystallization from hot methanol gave the metal complexes:

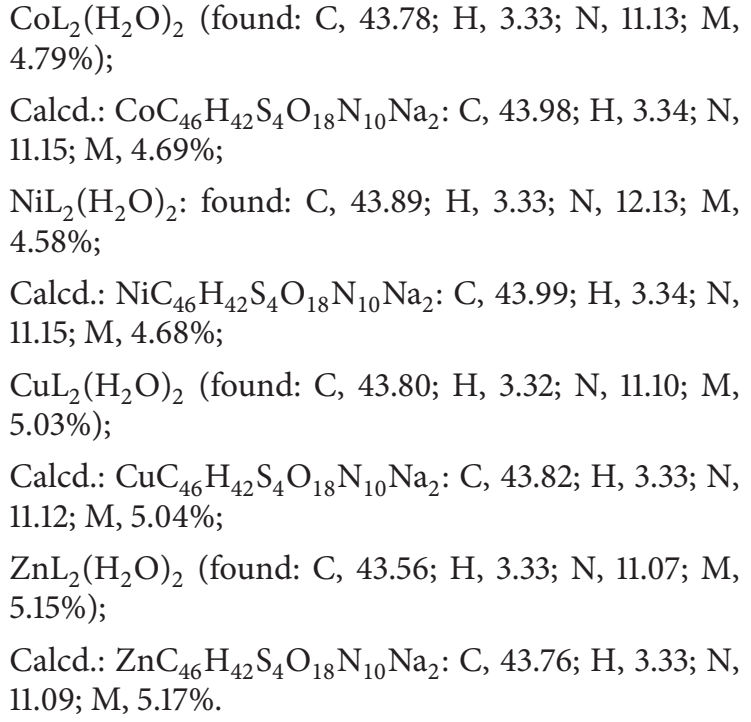
$4.79 \%)$;

Calcd.: $\mathrm{CoC}_{46} \mathrm{H}_{42} \mathrm{~S}_{4} \mathrm{O}_{18} \mathrm{~N}_{10} \mathrm{Na}_{2}$ : C, 43.98; H, 3.34; N, 11.15; M, 4.69\%;

$\mathrm{NiL}_{2}\left(\mathrm{H}_{2} \mathrm{O}\right)_{2}$ : found: $\mathrm{C}, 43.89 ; \mathrm{H}, 3.33 ; \mathrm{N}, 12.13 ; \mathrm{M}$, $4.58 \%$;

Calcd.: $\mathrm{NiC}_{46} \mathrm{H}_{42} \mathrm{~S}_{4} \mathrm{O}_{18} \mathrm{~N}_{10} \mathrm{Na}_{2}$ : C, 43.99; $\mathrm{H}, 3.34 ; \mathrm{N}$, 11.15; M, 4.68\%;

$\mathrm{CuL}_{2}\left(\mathrm{H}_{2} \mathrm{O}\right)_{2}$ (found: $\mathrm{C}, 43.80 ; \mathrm{H}, 3.32 ; \mathrm{N}, 11.10 ; \mathrm{M}$, $5.03 \%)$;

Calcd.: $\mathrm{CuC}_{46} \mathrm{H}_{42} \mathrm{~S}_{4} \mathrm{O}_{18} \mathrm{~N}_{10} \mathrm{Na}_{2}: \mathrm{C}, 43.82 ; \mathrm{H}, 3.33 ; \mathrm{N}$, 11.12; M, 5.04\%;

$\mathrm{ZnL}_{2}\left(\mathrm{H}_{2} \mathrm{O}\right)_{2}$ (found: C, 43.56; H, 3.33; N, 11.07; M, $5.15 \%)$;

Calcd.: $\mathrm{ZnC}_{46} \mathrm{H}_{42} \mathrm{~S}_{4} \mathrm{O}_{18} \mathrm{~N}_{10} \mathrm{Na}_{2}: \mathrm{C}, 43.76 ; \mathrm{H}, 3.33 ; \mathrm{N}$, 11.09; M, 5.17\%.

2.4. Analyses and Instrumentation. The IR spectra were recorded on a Perkin Elmer 157 instrument in anhydrous $\mathrm{KBr}$ pellets in the range of $4000-400 \mathrm{~cm}^{-1}$. A Unicam UV2-300 spectrometer was used to obtain electronic spectra in DMF solutions. The molar conductivities were determined by using OK-102 (Hungary) conductivity meter. The melting points were determined by using Sanyo Gallenkamp apparatus. The magnetic susceptibility measurement was made on a Faraday balance at room temperature. The metal contents of the complexes were determined by atomic absorption technique using Varian-AA775 spectrophotometer. C, H, and $\mathrm{N}$ were analysed using M.L.W. microelementary CHN analyser. The heating curves (TG and DTA) were carried out in a Netzsch TG 209C thermobalance with a sample mass of $10 \mathrm{mg}$ over the temperature range of $20-1000^{\circ} \mathrm{C}$ using a heating rate of $10^{\circ} \mathrm{C}$. The measurements were carried out in nitrogen atmosphere (flow rate of $40 \mathrm{~mL} \mathrm{~min}{ }^{-1}$ ) using alumina crucibles. The ${ }^{1} \mathrm{H}$ and ${ }^{13} \mathrm{C}$ NMR spectra were recorded on a Varian Gemini $300 \mathrm{BB}$ at room temperature in the same solvent $\mathrm{CDCl}_{3}$.

\subsection{Antimicrobial Assay}

2.5.1. Antimicrobial Activity. In vitro antimicrobial tests were carried out by an adapted agar-disc diffusion technique using $0.5 \mathrm{McF}$ arland suspension of bacteria obtained from $24 \mathrm{~h}$ cultures. The antimicrobial activities of the synthesized compounds were determined against six Gram-negative (Escherichia coli 13529, Escherichia coli 12147, Klebsiella pneumoniae 1204, Klebsiella pneumoniae 13420, Pseudomonas aeruginosa 1246, and Pseudomonas aeruginosa 13202) microbial strains and three Gram-positive (Staphylococcus aureus MRSA 1263, Staphylococcus aureus 13209, and Bacillus subtilis 12488) microbial strains. The compounds were solubilised in dimethylsulfoxide to a final concentration of $1 \mathrm{mg} / \mathrm{mL}$. A volume of $10 \mu \mathrm{L}$ of each tested compounds solution was distributed directly on the solid medium previously seeded with the microbial inoculums. The inoculated plates were incubated for $24 \mathrm{~h}$ at $37^{\circ} \mathrm{C}$. Antimicrobial activity was assessed by measuring the growth inhibition zones diameters [23-27].

2.5.2. Determination of Minimum Inhibitory Concentration (MIC). The quantitative assay of the minimal inhibitory concentration (MIC, $\mu \mathrm{g} / \mathrm{mL}$ ) was based on liquid medium twofold microdilutions. After $24 \mathrm{~h}$ of incubation at $37^{\circ} \mathrm{C}$, the bactericidal activity was quantified by measuring the absorbance of the liquid culture at $620 \mathrm{~nm}$.

2.5.3. Assessment of Biofilm Development on the Inert Substratum by the Micro-Titer Method. At the end of the MIC assay experiment, the plastic wells were emptied, washed three times with phosphate buffered saline (PBS), and fixed with cold methanol and the bacterial biofilm formed on the plastic walls was stained with $1 \%$ violet crystal solution for 30 minutes and then resuspended in 30\% acetic acid. The intensity of the colored suspensions was assessed by measuring the absorbance at $490 \mathrm{~nm}$; the obtained values being directly proportional with the number of bacterial cells adhered to the plastic wall [23-27].

\section{Results and Discussion}

The Schiff base ligand was prepared by refluxing the appropriate amount of cefotaxime with salicylaldehyde in methanol. The structure of synthesized Schiff base ligand was established by ${ }^{1} \mathrm{H}$ and ${ }^{13} \mathrm{C}$ NMR spectra, IR spectrum and microanalytical data. The metal complexes of ligand were prepared by the stoichiometric reaction of the corresponding metal(II) chloride with the ligand in a molar ratio $\mathrm{M}: \mathrm{L}$ of $1: 2$. The complexes were obtained as air-stable amorphous solids which decompose without melting. They are insoluble in water, partially soluble in methanol and ethanol, totally soluble in DMF and DMSO. The molar conductivities of the complexes measured in DMF $\left(10^{-3} \mathrm{~mol} \cdot \mathrm{L}^{-1}\right.$ at room 
TABLE $1:{ }^{1} \mathrm{H}$ and ${ }^{13} \mathrm{C}$ NMR spectral data of the ligand and $\mathrm{Zn}$ (II) complex.

\begin{tabular}{|c|c|c|}
\hline Compound & ${ }^{1} \mathrm{H}$ NMR $\delta(\mathrm{ppm})$ & ${ }^{13} \mathrm{C}$ NMR $\delta(\mathrm{ppm})$ \\
\hline $\begin{array}{l}\text { Schiff base (L) } \\
\mathrm{C}_{23} \mathrm{H}_{20} \mathrm{~S}_{2} \mathrm{O}_{8} \mathrm{~N}_{5} \mathrm{Na}\end{array}$ & $\begin{array}{l}2.10\left(3 \mathrm{H}, \mathrm{s}, \mathrm{COOCH}_{3}\right) ; 4.72,4.90(2 \mathrm{H}, \mathrm{AB} \\
\left.J=12.2 \mathrm{~Hz}, \mathrm{C}_{3}-\mathrm{CH}_{2}\right) ; 3.40,3.67(2 \mathrm{H}, \mathrm{AB} \\
\left.J=17.2 \mathrm{~Hz}, \mathrm{C}_{2}-\mathrm{H}_{2}\right) ; 5.22(1 \mathrm{H}, \mathrm{d}, J=4.6 \mathrm{~Hz} \\
\left.\mathrm{C}_{5}-\mathrm{H} \beta \text {-lactam }\right) ; 5.79\left(1 \mathrm{H}, \mathrm{d}, J=4.6 \mathrm{~Hz}, \mathrm{C}_{7}-\mathrm{H}\right. \\
\beta \text {-lactam }) ; 9.53(1 \mathrm{H}, \mathrm{s},-\mathrm{NH}-\mathrm{CO}) ; 3.99(3 \mathrm{H}, \mathrm{s} \\
\left.\mathrm{OCH}_{3}\right) ; 6.73(1 \mathrm{H}, \mathrm{s}, \text { thiazolyl-C } \\
-\mathrm{HC}-\mathrm{H}) ; 8.7(1 \mathrm{H}, \mathrm{s}, \\
-\mathrm{HC}) ; 10.2(1 \mathrm{H}, \mathrm{s},-\mathrm{OH}) ; 7.5(4 \mathrm{H}, \mathrm{m},- \text { phenyl })\end{array}$ & $\begin{array}{l}\text { 163.0; } 143.4 ; 109.9\left(\mathrm{C}_{17} ; \mathrm{C}_{15} ; \mathrm{C}_{16} \text {-thiazole ring }\right) ; \\
168.39\left(\mathrm{C}_{13}\right) ; 169.3 ;\left(\mathrm{C}_{12}\right) ; 58.12 ; 65.4 ; 171.4\left(\mathrm{C}_{5} ; \mathrm{C}_{7} ;\right. \\
\left.\mathrm{C}_{6} \beta \text {-lactam }\right) ; 139.5 ; 112.2 ; 26.2\left(\mathrm{C}_{4} ; \mathrm{C}_{3} ; \mathrm{C}_{2}\right) ; 58.3 \\
\left(\mathrm{C}_{9}\right) ; 163.9\left(\mathrm{C}_{10}\right) ; 21.6\left(\mathrm{C}_{11}\right) ; 165.0\left(\mathrm{C}_{8}\right) ; 62.7\left(\mathrm{C}_{14}\right) ; \\
163.62(-\mathrm{HC}=\mathrm{N}) ; 157.82\left(\mathrm{C}_{20} \text { phenyl }\right) ; 132.24 ; \\
130.46 ; 121.25 ; 117.43 ; 112.87\left(\mathrm{C}_{19}, \mathrm{C}_{21}, \mathrm{C}_{22}, \mathrm{C}_{23}, \mathrm{C}_{24}\right. \\
\text { phenyl })\end{array}$ \\
\hline $\begin{array}{l}\mathrm{ZnL}_{2}\left(\mathrm{H}_{2} \mathrm{O}\right)_{2} \\
\mathrm{ZnC}_{46} \mathrm{H}_{42} \mathrm{~S}_{4} \mathrm{O}_{18} \mathrm{~N}_{10} \mathrm{Na}_{2}\end{array}$ & $\begin{array}{l}2.10\left(3 \mathrm{H}, \mathrm{s}, \mathrm{COOCH}_{3}\right) ; 4.72,4.90(2 \mathrm{H}, \mathrm{AB}, \\
\left.J=12.2 \mathrm{~Hz}, \mathrm{C}_{3}-\mathrm{CH}_{2}\right) ; 3.40,3.67(2 \mathrm{H}, \mathrm{AB}, \\
\left.J=17.2 \mathrm{~Hz}, \mathrm{C}_{2}-\mathrm{H}_{2}\right) ; 5.22(1 \mathrm{H}, \mathrm{d}, J=4.6 \mathrm{~Hz}, \\
\left.\mathrm{C}_{5}-\mathrm{H} \beta \text {-lactam }\right) ; 5.79\left(1 \mathrm{H}, \mathrm{d}, J=4.6 \mathrm{~Hz}, \mathrm{C}_{7}-\mathrm{H}\right. \\
\beta \text {-lactam }) ; 9.53(1 \mathrm{H}, \mathrm{s},-\mathrm{NH}-\mathrm{CO}) ; 3.99(3 \mathrm{H}, \mathrm{s}, \\
\left.\mathrm{OCH}_{3}\right) ; 6.73(1 \mathrm{H}, \mathrm{s}, \text { thiazolyl-C } \\
-\mathrm{HC}-\mathrm{H}) ; 8.96(1 \mathrm{H}, \mathrm{s}, \\
-\mathrm{HC}) ; .5(4 \mathrm{H}, \mathrm{m},- \text { phenyl })\end{array}$ & $\begin{array}{l}163.0 ; 143.4 ; 109.9\left(\mathrm{C}_{17} ; \mathrm{C}_{15} ; \mathrm{C}_{16} \text { thiazole ring }\right) ; \\
168.39\left(\mathrm{C}_{13}\right) ; 169.3 ;\left(\mathrm{C}_{12}\right) ; 58.12 ; 65.4 ; 171.4\left(\mathrm{C}_{5} ; \mathrm{C}_{7} ;\right. \\
\left.\mathrm{C}_{6} \beta \text {-lactam }\right) ; 139.5 ; 112.2 ; 26.2\left(\mathrm{C}_{4} ; \mathrm{C}_{3} ; \mathrm{C}_{2}\right) ; 58.3 \\
\left(\mathrm{C}_{9}\right) ; 163.9\left(\mathrm{C}_{10}\right) ; 21.6\left(\mathrm{C}_{11}\right) ; 165.0\left(\mathrm{C}_{8}\right) ; 62.7\left(\mathrm{C}_{14}\right) ; \\
168.16(-\mathrm{HC}=\mathrm{N}) ; 157.82\left(\mathrm{C}_{20} \text { phenyl }\right) ; 132.24 ; \\
\text { 130.46;121.25; 117.43;112.87 }\left(\mathrm{C}_{19}, \mathrm{C}_{21}, \mathrm{C}_{22}, \mathrm{C}_{23}, \mathrm{C}_{24}\right. \\
\text { phenyl })\end{array}$ \\
\hline
\end{tabular}

TABLE 2: Relevant IR data $\left(\mathrm{cm}^{-1}\right)$ of the ligand and its complexes.

\begin{tabular}{|c|c|c|c|c|c|c|c|c|c|}
\hline Compound & $v(\mathrm{OH})$ & $v\left(\mathrm{NH}_{2}\right)$ & $\begin{array}{c}\nu(\mathrm{OH}) \\
\text { associate }\end{array}$ & $\begin{array}{c}\nu(\mathrm{C}=\mathrm{O}) \\
\beta \text {-lact }\end{array}$ & $\begin{array}{c}\nu(\mathrm{C}=\mathrm{N}) \\
\text { azm. }\end{array}$ & $\begin{array}{c}\nu(\mathrm{C}=\mathrm{O}) \\
\text { amide } \\
\nu(\mathrm{C}=\mathrm{O}) \\
\text { ester }\end{array}$ & $\begin{array}{c}\nu(\mathrm{C}-\mathrm{O}) \\
\text { phenolic }\end{array}$ & $\begin{array}{c}\delta_{r}\left(\mathrm{H}_{2} \mathrm{O}\right) \\
\delta_{w}\left(\mathrm{H}_{2} \mathrm{O}\right) \\
\text { coord. }\end{array}$ & $\begin{array}{l}\nu(\mathrm{M}-\mathrm{O}) \\
\nu(\mathrm{M}-\mathrm{N})\end{array}$ \\
\hline Cefotaxime- $\mathrm{Na}$ & - & 3442 & - & 1776 & - & 1640 & - & - & - \\
\hline Schiff base (L) & - & - & 2800 & 1770 & 1657 & 1645 & 1274 & - & - \\
\hline$\left[\mathrm{CoL}_{2}\left(\mathrm{H}_{2} \mathrm{O}\right)_{2}\right]$ & 3530 & - & - & 1770 & 1624 & 1640 & 1295 & $\begin{array}{l}863 \\
539\end{array}$ & $\begin{array}{l}419 \\
510\end{array}$ \\
\hline$\left[\mathrm{NiL}_{2}\left(\mathrm{H}_{2} \mathrm{O}\right)_{2}\right]$ & 3545 & - & - & 1770 & 1623 & 1640 & 1305 & $\begin{array}{l}863 \\
541\end{array}$ & $\begin{array}{l}420 \\
520\end{array}$ \\
\hline$\left[\mathrm{CuL}_{2}\left(\mathrm{H}_{2} \mathrm{O}\right)_{2}\right]$ & 3540 & - & - & 1770 & 1620 & 1645 & 1295 & $\begin{array}{l}860 \\
545\end{array}$ & $\begin{array}{l}427 \\
514\end{array}$ \\
\hline$\left[\mathrm{ZnL}_{2}\left(\mathrm{H}_{2} \mathrm{O}\right)_{2}\right]$ & 3543 & - & - & 1770 & 1630 & 1640 & 1310 & $\begin{array}{l}857 \\
545\end{array}$ & $\begin{array}{l}423 \\
517\end{array}$ \\
\hline
\end{tabular}

temperature) have lower values $\left(13-18 \Omega^{-1} \mathrm{~cm}^{2} \mathrm{~mol}^{-1}\right)$ indicating their nonelectrolyte nature [28]. The elemental analysis and the physical measurements permit the suggestion of the empirical formulae: $\mathrm{ML}_{2}\left(\mathrm{H}_{2} \mathrm{O}\right)_{2}$ where $\mathrm{L}=$ Schiff base and $\mathrm{M}$ $=\mathrm{Co}(\mathrm{II}), \mathrm{Ni}(\mathrm{II}), \mathrm{Cu}(\mathrm{II})$ and $\mathrm{Zn}(\mathrm{II})$.

3.1. ${ }^{1} \mathrm{H}$ and ${ }^{13} \mathrm{C}$ NMR Spectra. The ${ }^{1} \mathrm{H}$ and ${ }^{13} \mathrm{C}$ NMR spectra of Schiff base and diamagnetic $\mathrm{Zn}$ (II) complex were performed. In the ${ }^{1} \mathrm{H}$ NMR spectrum of the ligand, the formation of Schiff base is supported by the presence of a singlet at $\delta=8.7 \mathrm{ppm}$ corresponding to the azomethine proton ($\mathrm{N}=\mathrm{CH}-)$ and a peak at $\delta=163.62 \mathrm{ppm}$ in the ${ }^{13} \mathrm{C}-\mathrm{NMR}$ spectrum (Table 1) [29]. The chemical structure of the Schiff base is presented in Figure 1.

The signal assigned to the azomethine proton in ${ }^{1} \mathrm{H}$ NMR spectrum of Schiff base shifted downfield in the spectrum of the $\mathrm{Zn}(\mathrm{II})$ complex $(\delta=8.96 \mathrm{ppm})$ indicating coordination through the azomethine nitrogen to the metallic ion. The signal of the phenolic proton in the free ligand at $\delta 12.8 \mathrm{ppm}$ (intramolecularly $\mathrm{H}$-bonded phenolic group) is absent in the spectrum of the complex, thus confirming the deprotonation of the phenolic group on complex formation.
The signal of the carbon atom from the azomethine group in ${ }^{13} \mathrm{C}-\mathrm{NMR}$ spectrum of the ligand is slightly shifted downfield $(\delta=168.16 \mathrm{ppm})$ in the spectrum of the $\mathrm{Zn}$ (II) complex due coordination.

3.2. Infrared Spectra. The IR data of the free cephalosporin, the Schiff base ligand (L), and its complexes are presented in Table 2 .

A comparison of the IR spectra of the free cephalosporin and the Schiff base ligand gives us the proof about the formation of the ligand Schiff base (L) between the cefotaxime$\mathrm{Na}$ and salicylaldehyde. The main bands in the IR spectrum of the free cephalosporin (cefotaxime-Na) are at 3442, 1776, and $1640 \mathrm{~cm}^{-1}$ attributed to $\nu\left(\mathrm{NH}_{2}\right), \nu(\mathrm{C}=\mathrm{O}) \beta$-lactam, and $v(\mathrm{C}=\mathrm{O})$ amide $+v(\mathrm{C}=\mathrm{O})$ ester, respectively. The IR Schiff base spectrum shows absorption bands at 2800, 1657, and $1274 \mathrm{~cm}^{-1}$. The broad absorption band at $c a .2800 \mathrm{~cm}^{-1}$ is due to an intramolecular hydrogen bond which shows the presence of $-\mathrm{OH}$ group in the ligand molecule which is situated in a favourable position (orto) towards the azomethine group to form this type of bond. The absorption band at $1657 \mathrm{~cm}^{-1}$ is attributed to $\nu(\mathrm{C}=\mathrm{N})$ stretching vibration and the 


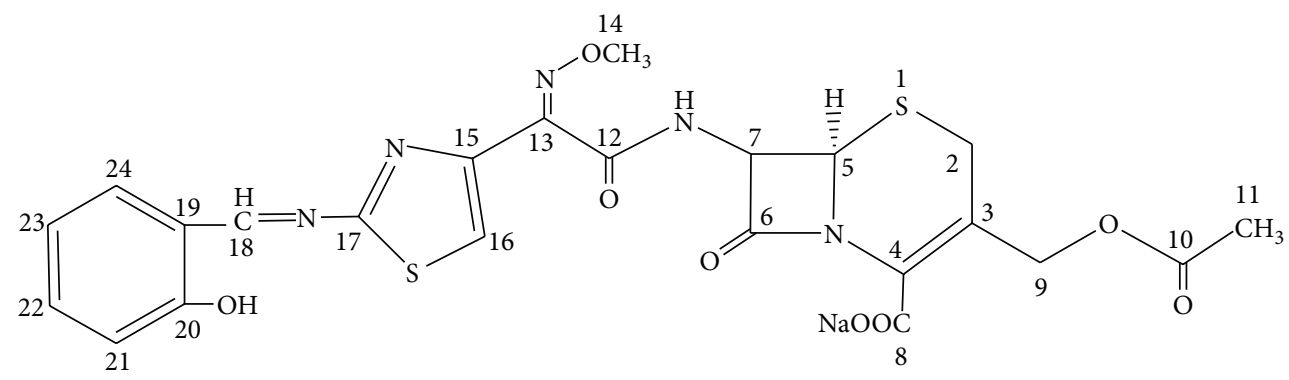

Figure 1: Chemical structure of the Schiff base.

absorption band $1275 \mathrm{~cm}^{-1}$ is attributed to $\nu(\mathrm{C}-\mathrm{O})$ phenolic. The bands attributed to $\nu(\mathrm{C}=\mathrm{O}) \beta$-lactam and $\nu(\mathrm{C}=\mathrm{O})$ amide $+\nu(\mathrm{C}=\mathrm{O})$ ester which are also presented in the IR spectrum of Schiff base are slightly shifted at 1770 and $1645 \mathrm{~cm}^{-1}$, respectively.

A comparison of the IR spectra of the complexes and those of the free Schiff base ligand allows us to determine the coordination sites that could be involved in chelation process (Figure 2). The spectra of these complexes contain a broad band around $3530-3545 \mathrm{~cm}^{-1}$ attributed to $\nu(\mathrm{OH})$. Additionally, the coordinated water presents $\delta \mathrm{r}\left(\mathrm{H}_{2} \mathrm{O}\right)$ rocking at $857-863 \mathrm{~cm}^{-1}$ and $\delta \mathrm{w}\left(\mathrm{H}_{2} \mathrm{O}\right)$ wagging at $539-545 \mathrm{~cm}^{-1}$ $[30,31]$. The band at $1657 \mathrm{~cm}^{-1}$ attributed to $\nu(\mathrm{HC}=\mathrm{N})$ from the Schiff base is shifted to lower values $\left(1620-1630 \mathrm{~cm}^{-1}\right)$ in the complexes, which suggests that the Schiff base ligand is coordinated to the metallic ion by the $\mathrm{N}$ atom in the azomethine group. The absorption band at $2800 \mathrm{~cm}^{-1}$ attributed to the formation of a intramolecular hydrogen bonding does no longer appear in the complexes spectra, which proves the deprotonation of $-\mathrm{OH}$ group. Likewise, the absorption band at $1274 \mathrm{~cm}^{-1}$ in the ligand spectrum attributed to the $v(\mathrm{C}-\mathrm{O})$ phenolic frequency appears at $\sim 21-36 \mathrm{~cm}^{-1}$ higher frequencies. These shifts indicate the participation of the $\mathrm{O}$ atom of the deprotonated hydroxyl group in the formation of the $\mathrm{M}-\mathrm{O}$ bonds. The metal complexes are also characterized by the appearance of some new bands at $510-520 \mathrm{~cm}^{-1}$ and $419-423 \mathrm{~cm}^{-1}$, which are assigned to $\nu(\mathrm{M}-\mathrm{O})$ and $\nu(\mathrm{M}-$ $\mathrm{N})$ stretching frequencies, respectively. The $\nu(\mathrm{C}=\mathrm{O}) \beta$-lactam and $v(\mathrm{C}=\mathrm{O})$ amide $+\nu(\mathrm{C}=\mathrm{O})$ ester frequencies at $1770 \mathrm{~cm}^{-1}$ and $1640 \mathrm{~cm}^{-1}$, respectively, in the Schiff base spectrum are not shifted in the complexes spectra, which means that these groups are not involved in the coordination. In conclusion, we can say that the Schiff base ligand is bidentately coordinated to the metallic ions with $\mathrm{N}$ and $\mathrm{O}$ atoms from azomethine and phenolic groups.

3.3. Electronic Spectra and Magnetic Moment Values. In order to obtain information regarding the coordination geometry of the complexes, the electronic spectra were determined at room temperature in DMF (Figure 3) and the data obtained were correlated with magnetic moment values and ligand field parameters: splitting energy (10Dq), interelectronic repulsion parameter $(B)$, and nephelauxetic ratio $(\beta)$ (Table 3$)$.
The electronic spectra of the ligand present two absorption bands at 38460 and $28570 \mathrm{~cm}^{-1}$, respectively, attributed to $\pi \rightarrow \pi^{*}$ and $n \rightarrow \pi^{*}$, respectively, determined by the $\mathrm{C}=\mathrm{O}$ and $\mathrm{C}=\mathrm{N}$ groups. These absorption bands also appear in the electronic spectra of the complexes, but they are shifted to $\sim 1500-5000 \mathrm{~cm}^{-1}$ lower values, which proves the coordination of the ligand to the central metallic ions. The electronic spectra of the Co(II) complex display two bands at $9570 \mathrm{~cm}^{-1}\left(\nu_{1}\right)$ and $19305 \mathrm{~cm}^{-1}\left(\nu_{3}\right)$, which are assigned to ${ }^{4} \mathrm{~T}_{1 \mathrm{~g}} \rightarrow{ }^{4} \mathrm{~T}_{2 \mathrm{~g}}(\mathrm{~F})\left(\nu_{1}\right)$ and ${ }^{4} \mathrm{~T}_{1 \mathrm{~g}}(\mathrm{~F}) \rightarrow{ }^{4} \mathrm{~T}_{1 \mathrm{~g}}(\mathrm{P})\left(v_{3}\right)$ transitions, respectively. These are the characteristic bands of high spin octahedral $\mathrm{Co}(\mathrm{II})$ complexes [32]. The ligand field parameters $(\mathrm{Dq}, B$, and $\beta$ ) are calculated using E. Koning equations [33], when only $v_{3}$ and $v_{1}$ bands are observed in the electronic spectra and the values are well within the range reported for the octahedral complexes [32, 34]. The value of the magnetic moment is $4.78 \mathrm{BM}$ for $\mathrm{Co}$ (II) complex which suggests three unpaired electrons in an octahedral environment [35]. The electronic spectrum of $\mathrm{Ni}$ (II) complex presents three $\mathrm{d} \rightarrow \mathrm{d}$ absorption bands at 10120, 16630, and $24880 \mathrm{~cm}^{-1}$ in octahedral environment corresponding to ${ }^{3} \mathrm{~A}_{2 \mathrm{~g}} \rightarrow{ }^{3} \mathrm{~T}_{2 \mathrm{~g}}(\mathrm{~F})\left(\nu_{1}\right),{ }^{3} \mathrm{~A}_{2 \mathrm{~g}} \rightarrow{ }^{3} \mathrm{~T}_{1 \mathrm{~g}}(\mathrm{~F})\left(\nu_{2}\right)$, and ${ }^{3} \mathrm{~A}_{2 \mathrm{~g}}(\mathrm{~F})$ $\rightarrow{ }^{3} \mathrm{~T}_{1 \mathrm{~g}}(\mathrm{P})\left(\nu_{3}\right)$ transitions $[32,34]$. The values obtained for $\mathrm{Dq}, B$, and $\beta$ are in agreement with the experimental ones for $\mathrm{Ni}$ (II) octahedral complexes [33]. The magnetic moment value of $\mathrm{Ni}$ (II) complex is $3.12 \mathrm{BM}$ indicating the presence of two unpaired electrons on $\mathrm{Ni}$ (II) ion and suggesting this complex to have an octahedral geometry $[35,36]$. The electronic spectrum of $\mathrm{Cu}$ (II) complex presents only one broad band with maximum centered at $14290 \mathrm{~cm}^{-1}$ typical for the copper (II) ion in an elongated distorted octahedral (tetragonal) geometry $[32,34]$. The magnetic moment value of $\mathrm{Cu}$ (II) complex is $1.86 \mathrm{BM}$ which indicates the presence of one unpaired electron on $\mathrm{Cu}(\mathrm{II})$ ion in a $\mathrm{d}^{9}$ system [37]. The electronic spectrum of $\mathrm{Zn}$ (II) complex does not contain $\mathrm{d} \rightarrow \mathrm{d}$ transitions, but presents only one band at $19800 \mathrm{~cm}^{-1}$, which may be attributed to a $\mathrm{L} \rightarrow \mathrm{M}$ charge transfer [32]. The $\mathrm{Zn}$ (II) complex was found to be diamagnetic as expected.

3.4. Thermal Studies. Thermogravimetric analyses for the $\mathrm{Co}(\mathrm{II}), \mathrm{Ni}(\mathrm{II})$, and $\mathrm{Cu}(\mathrm{II})$ complexes were carried out from room temperature to $900^{\circ} \mathrm{C}$ and show nearly the same pattern (Figure 4). Calculated and experimental mass losses are comparable. The data are given in Table 4 . At $70-127^{\circ} \mathrm{C}$, 


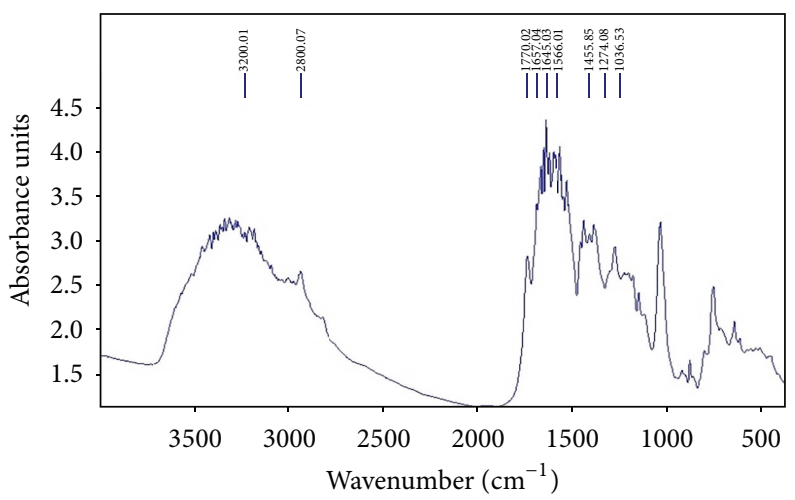

(a)

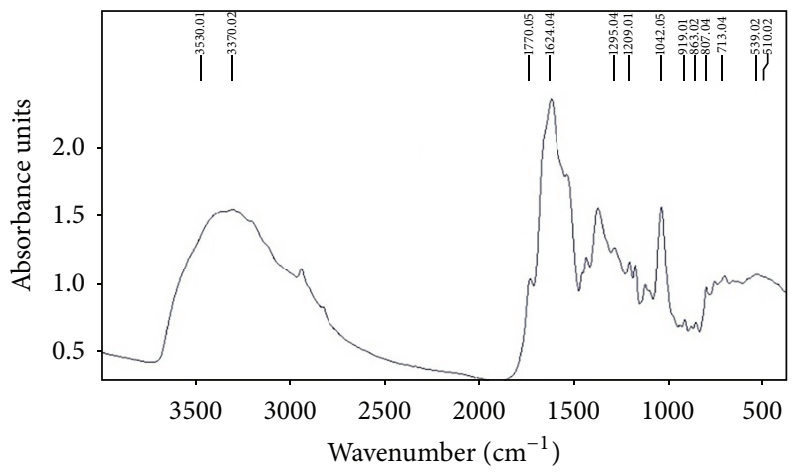

(b)

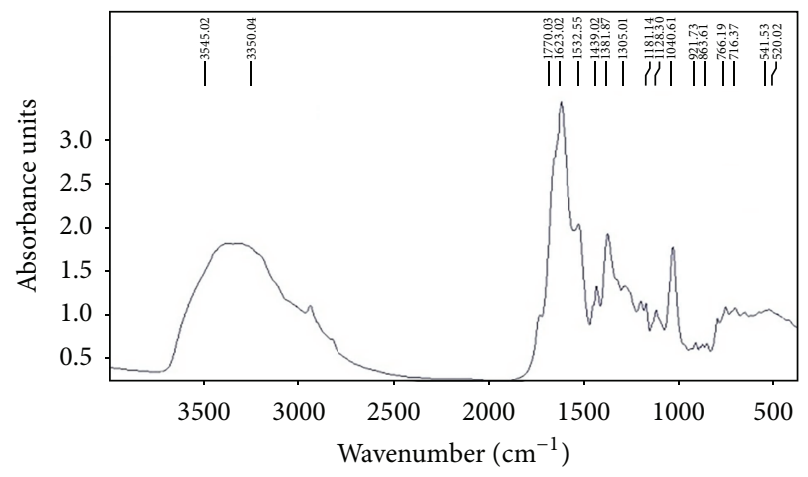

(c)

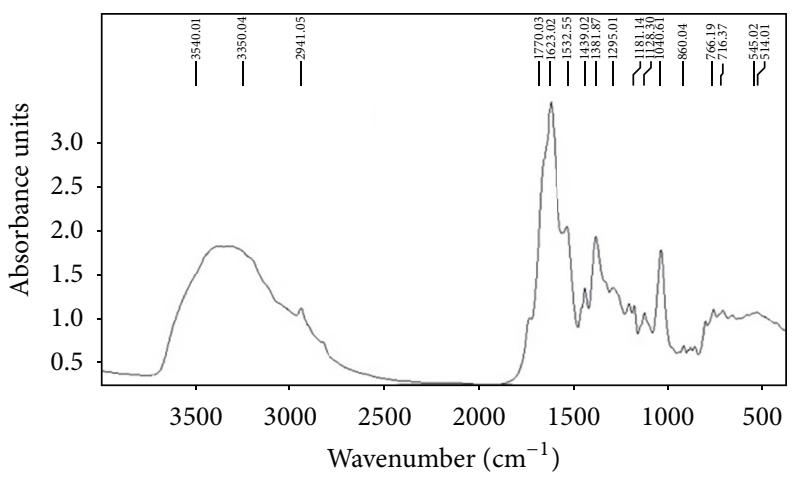

(d)

FIGURE 2: IR spectra of the Schiff base (a) and its complexes: $\left[\mathrm{CoL}_{2}\left(\mathrm{H}_{2} \mathrm{O}\right)_{2}\right](\mathrm{b}) ;\left[\mathrm{NiL}_{2}\left(\mathrm{H}_{2} \mathrm{O}\right)_{2}\right](\mathrm{c}) ;\left[\mathrm{CuL}_{2}\left(\mathrm{H}_{2} \mathrm{O}\right)_{2}\right](\mathrm{d})$.

the experimental mass loss of $11.53-11.79 \%$ may be due to the loss of two $\mathrm{CH}_{3} \mathrm{COOCH}_{3}$ molecules in complexes. Weight loss in the range $117-207^{\circ} \mathrm{C}$ with experimental mass loss of $2.35-2.55 \%$ in all the complexes indicates the loss of two coordinated water molecules (calculated value, $2.86 \%$ ). This temperature required for water loss indicates that water molecules are strongly bonded to the metal ion and this type of thermal behaviour is characteristic of coordinated water molecules [38]. From $197^{\circ} \mathrm{C}$ to $463^{\circ} \mathrm{C}$, a sharp decrease in weight indicated the loss of fragments from two Schiff base molecules from the complexes with experimental mass loss of $46.32-48.32 \%$ for all the complexes, respectively. In the final stage, which occurs in the $453-605^{\circ} \mathrm{C}$ temperature range, both decomposition products with experimental mass loss of $31.75-32.75 \%$ for the three complexes and a black residue are eliminated. Chemical analysis of the black final residue corresponds to the metallic oxide. The stages of thermal decomposition for the $\mathrm{Co}(\mathrm{II}), \mathrm{Ni}(\mathrm{II})$, and $\mathrm{Cu}(\mathrm{II})$ complexes may be summarized by the scheme presented in Scheme 1. In conclusion, TG experiments revealed the nature of complex species as anhydrous and confirmed their compositions suggested by the analytical data.

3.5. Molecular Modelling. Molecular structure of the Schiff base ligand and its metal complexes were studied using programs dedicated to the chemical modeling and quantomolecular calculations of chemical properties. The molecular geometries of the compounds were obtained by molecular orbitals quantum methods, with the optimization being done using the molecular mechanics program Hyperchem 8 [39]. 


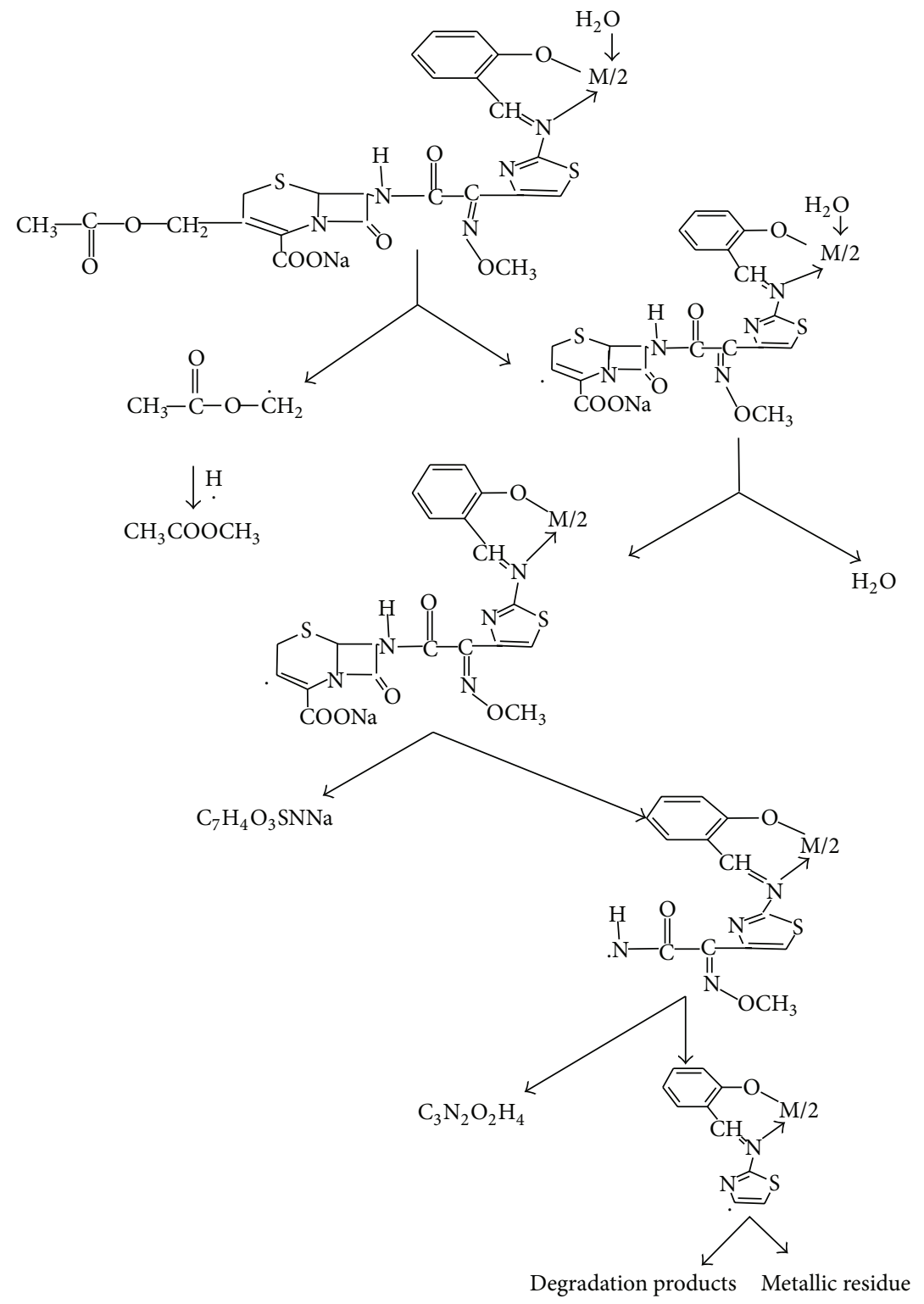

Scheme 1: Fragmentation of $\mathrm{Co}(\mathrm{II}), \mathrm{Ni}(\mathrm{II})$, and $\mathrm{Cu}(\mathrm{II})$ complexes following the thermal decomposition.

TABLE 3: Absorption maxima from electronic spectra, magnetic moments, and crystal field parameters for Schiff base (L) and its complexes.

\begin{tabular}{|c|c|c|c|c|c|c|}
\hline \multirow{2}{*}{ Compound } & \multirow{2}{*}{$\begin{array}{c}\text { Absorption } \\
\text { maxima }\left(\mathrm{cm}^{-1}\right)\end{array}$} & \multirow{2}{*}{ Assignments } & \multirow{2}{*}{$\mu_{\mathrm{eff}}($ B.M.) } & \multicolumn{3}{|c|}{ Crystal field parameters } \\
\hline & & & & $10 \mathrm{Dq}\left(\mathrm{cm}^{1}\right)$ & $B\left(\mathrm{~cm}^{-1}\right)$ & $\beta$ \\
\hline $\mathrm{L}$ & $\begin{array}{l}38460 \\
28570\end{array}$ & $\begin{aligned} \pi & \rightarrow \pi^{*} \\
n & \rightarrow \pi^{*}\end{aligned}$ & - & - & - & - \\
\hline$\left[\mathrm{CoL}_{2}\left(\mathrm{H}_{2} \mathrm{O}\right)_{2}\right]$ & $\begin{array}{c}22936 \\
19305\left(v_{3}\right) \\
9570\left(v_{1}\right)\end{array}$ & $\begin{array}{c}n \rightarrow \pi^{*} \\
{ }^{4} \mathrm{~T}_{\mathrm{lg}}(\mathrm{F}) \rightarrow{ }^{4} \mathrm{~T}_{\mathrm{lg}}(\mathrm{P}) \\
{ }^{4} \mathrm{~T}_{\mathrm{lg}} \rightarrow{ }^{4} \mathrm{~T}_{2 \mathrm{~g}}(\mathrm{~F})\end{array}$ & 4.78 & 1071 & 724 & 0.748 \\
\hline$\left[\mathrm{CuL}_{2}\left(\mathrm{H}_{2} \mathrm{O}\right)_{2}\right]$ & $\begin{array}{c}23094 \\
14290\left(v_{1}\right)\end{array}$ & $\begin{aligned} n & \rightarrow \pi^{*} \\
d_{x y} & \rightarrow d_{x^{2}-y^{2}}\end{aligned}$ & 1.86 & 1429 & - & - \\
\hline$\left[\mathrm{NiL}_{2}\left(\mathrm{H}_{2} \mathrm{O}\right)_{2}\right]$ & $\begin{array}{c}27070 \\
24880\left(v_{3}\right) \\
16630\left(v_{2}\right) \\
10120\left(v_{1}\right)\end{array}$ & $\begin{aligned} n & \rightarrow \pi^{*} \\
{ }^{3} \mathrm{~A}_{2 \mathrm{~g}}(\mathrm{~F}) & \rightarrow{ }^{3} \mathrm{~T}_{1 \mathrm{~g}}(\mathrm{P}) \\
{ }^{3} \mathrm{~A}_{2 \mathrm{~g}}(\mathrm{~F}) & \rightarrow{ }^{3} \mathrm{~T}_{1 \mathrm{~g}}(\mathrm{~F}) \\
{ }^{3} \mathrm{~A}_{2 \mathrm{~g}}(\mathrm{~F}) & \rightarrow{ }^{3} \mathrm{~T}_{2 \mathrm{~g}}(\mathrm{~F})\end{aligned}$ & 3.12 & 1012 & 793 & 0.752 \\
\hline$\left[\mathrm{ZnL}_{2}\left(\mathrm{H}_{2} \mathrm{O}\right)_{2}\right]$ & 19800 & C.T. $(\mathrm{L} \rightarrow \mathrm{M})$ & & - & - & - \\
\hline
\end{tabular}




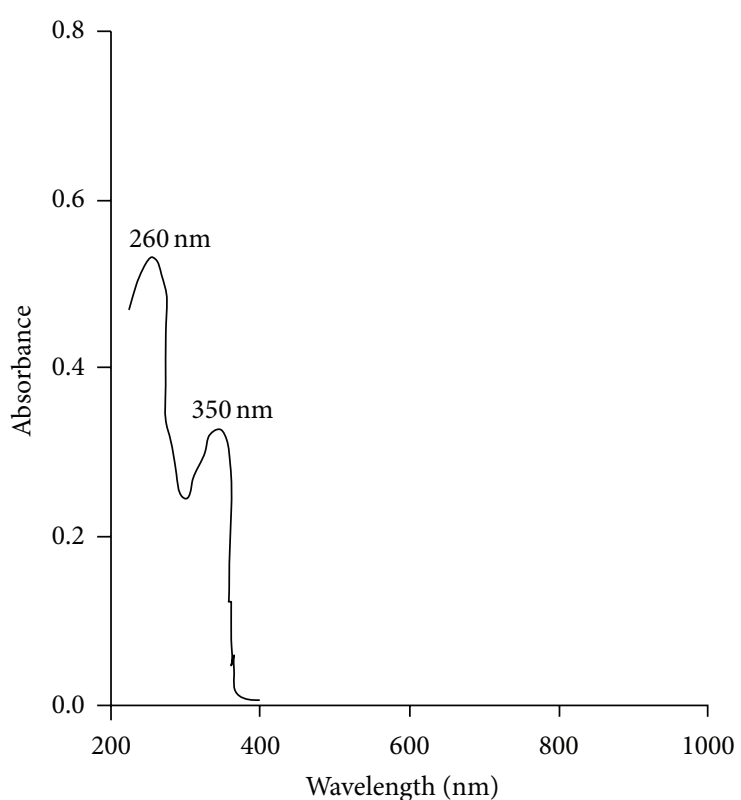

(a)

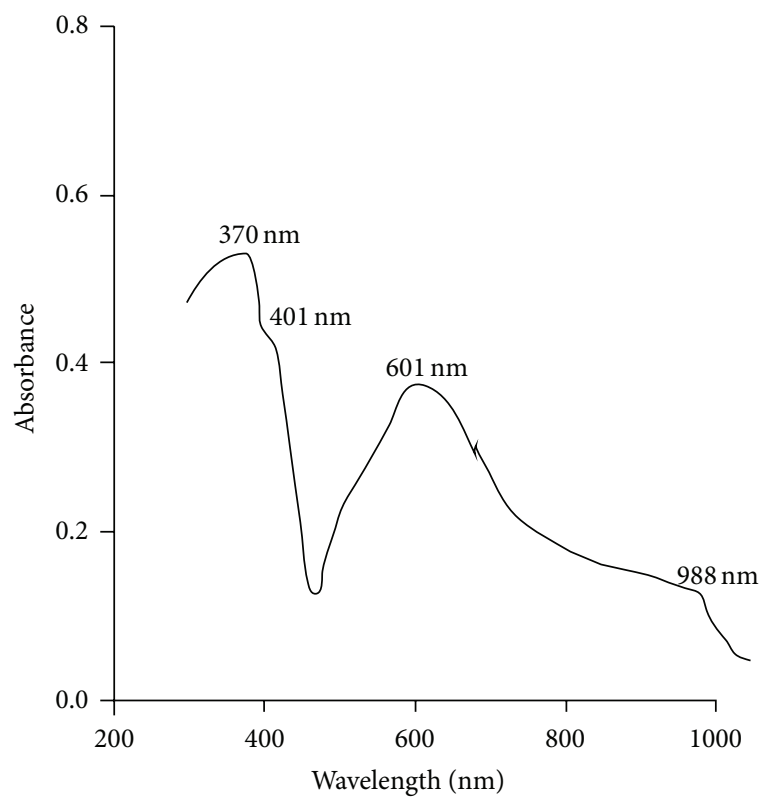

(c)

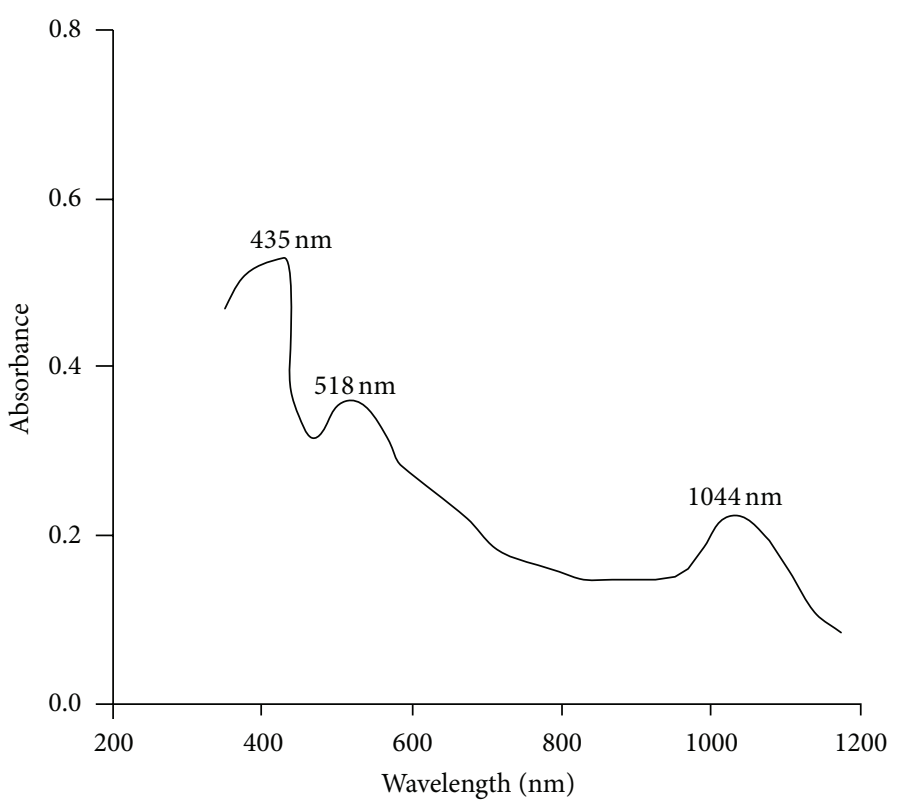

(b)

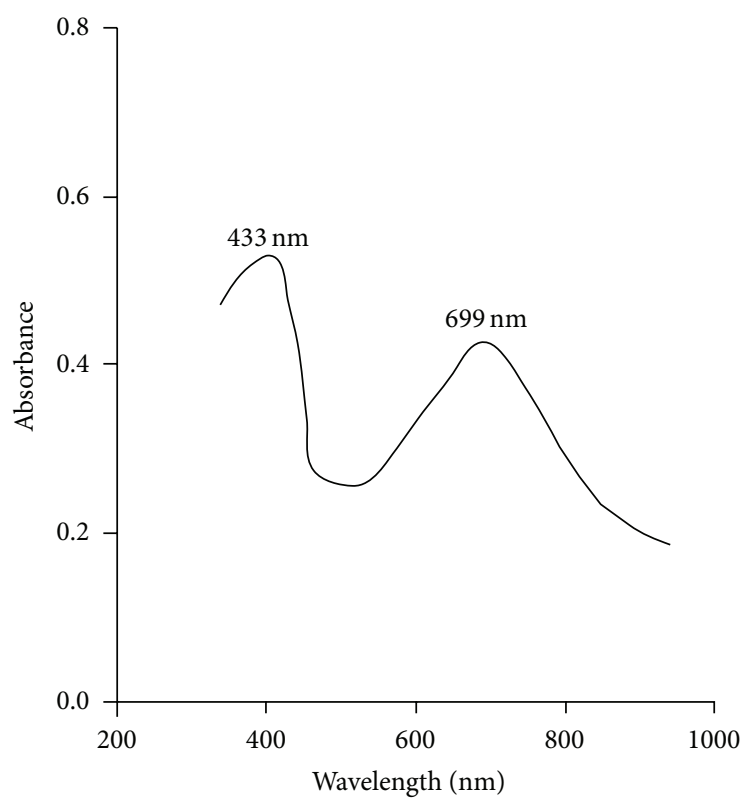

(d)

FIGURE 3: UV-Vis spectra of the Schiff base (a) and its complexes: $\left[\mathrm{CoL}_{2}\left(\mathrm{H}_{2} \mathrm{O}\right)_{2}\right](\mathrm{b}) ;\left[\mathrm{NiL}_{2}\left(\mathrm{H}_{2} \mathrm{O}\right)_{2}\right](\mathrm{c}) ;\left[\mathrm{CuL}_{2}\left(\mathrm{H}_{2} \mathrm{O}\right)_{2}\right](\mathrm{d})$.

Some of the structural data (called descriptors) obtained by Hyperchem program are presented in Table 5.

In Figure 5 the molecular structure of the complex $\left[\mathrm{NiL}_{2}\left(\mathrm{H}_{2} \mathrm{O}\right)_{2}\right]$ is presented, in which the interatomic bonds in red correspond to the labile areas of the molecule, areas where the interatomic bonds break after thermal degradation. This fact is confirmed by the increase in the interatomic distances in the complex compared with the ligand: distance $\mathrm{C}_{38}-\mathrm{C}_{39}$ (from $1.5182 \AA$ in the ligand to $1.5297 \AA$ in the complex), distance $\mathrm{N}_{1}-\mathrm{C}_{46}$ (from $1.4435 \AA$ in the ligand to $1.4520 \AA$ in the complex), and distance $\mathrm{C}_{3}-\mathrm{C}_{4}$ (from $1.3486 \AA$ in the ligand to $1.3596 \AA$ in the complex), respectively. Similar structural changes are also found in the other complexes. Instead, the interatomic distances that decrease in length after coordination indicate an increase in their stability. All these results are consistent with the results of the thermogravimetric analysis.

The structural analysis of the chemical compounds included in this study led to other parameters, $E$ : total energy of the molecule, $M$ : molecular mass, $V$ : molecular volume, $\alpha$ : molecular polarizability; $\mu$ : dipole moment, and OV: ovality index, which are presented in Table 6 .

The results presented in Table 6 indicate the following. 


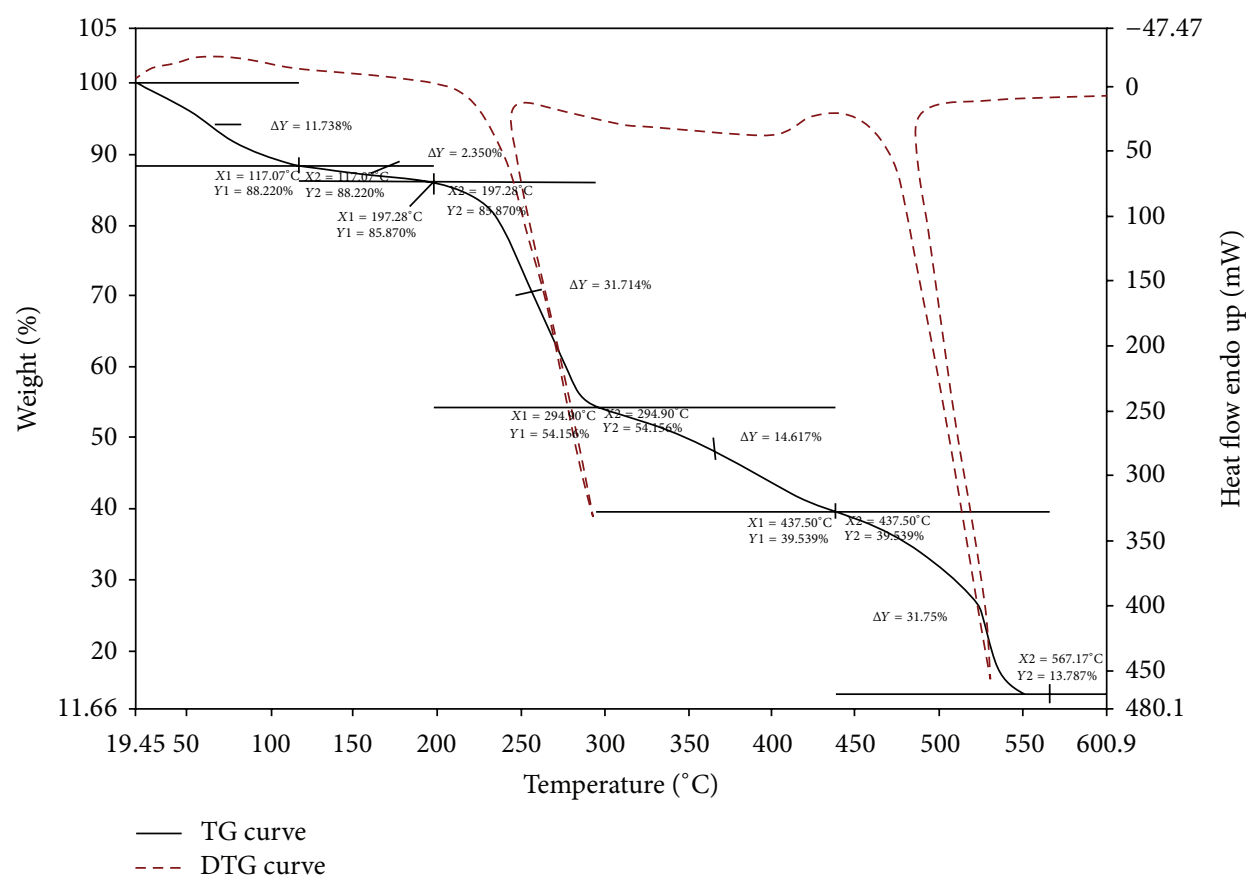

(a)

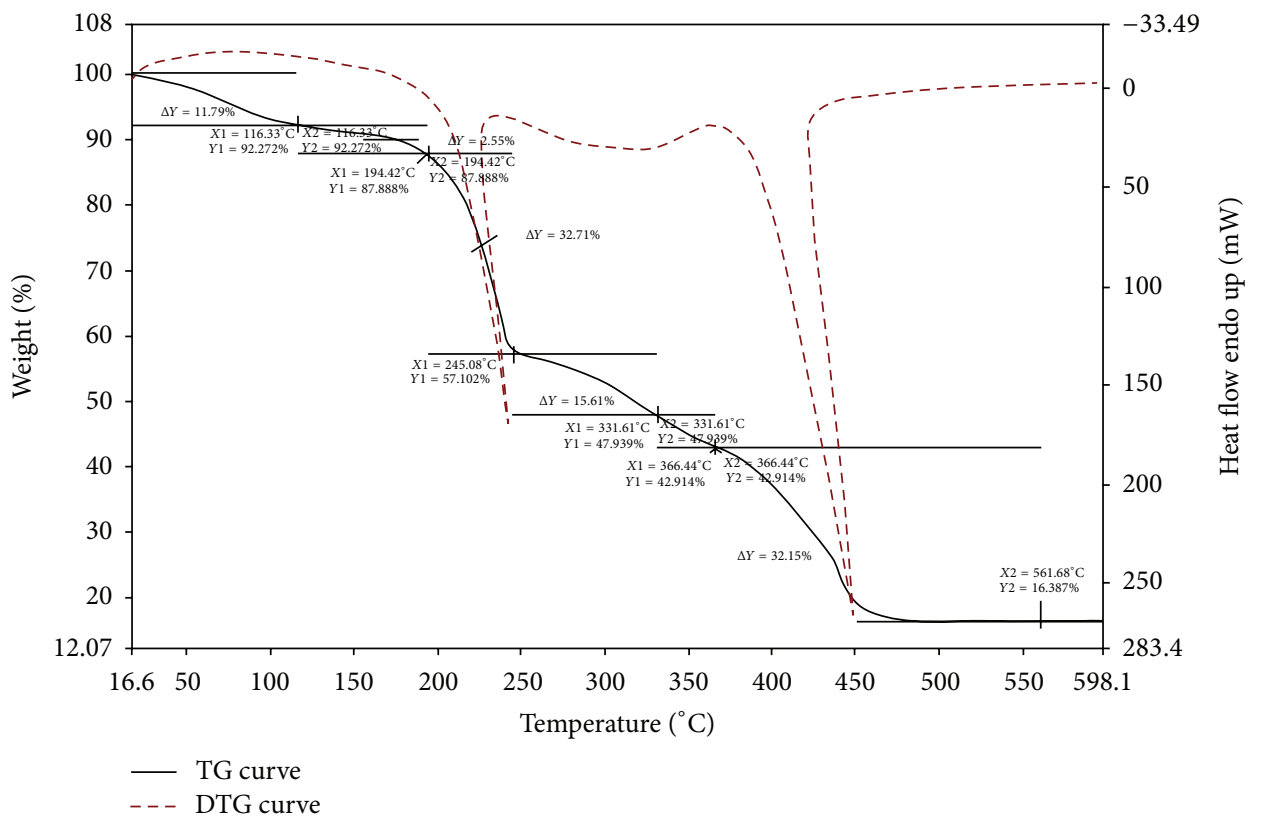

(b)

FIgURE 4: Thermogravimetric curves for $\mathrm{Ni}(\mathrm{II})$ complex (a) and $\mathrm{Cu}(\mathrm{II})$ complex (b).

(i) Total energy $E$ has the highest value $(287.481 \mathrm{kcal} /$ mol) for the complex $\left[\mathrm{CuL}_{2}\left(\mathrm{H}_{2} \mathrm{O}\right)_{2}\right]$, which explains its high reactivity and the lowest value $(277.223 \mathrm{kcal} /$ mol) for the complex $\left[\mathrm{NiL}_{2}\left(\mathrm{H}_{2} \mathrm{O}\right)_{2}\right]$, which explains its increased stability. These results are accordant with the biological activity which indicates that the lowest antimicrobial spectrum was noticed for the $\mathrm{Ni}$ (II) complex, while the largest inhibitions zones were exhibited by the $\mathrm{Cu}(\mathrm{II})$ complex (Table 7); this last complex compound proved to be the most efficient also in the quantitative assay (Table 8).

(ii) The variation of the $V, \mu$, and $\alpha$ descriptors, calculated and presented in Table 6 , is consistent with the molecular mass of the complex compounds: the values of these descriptors increase along with the increase in the molecular mass. 


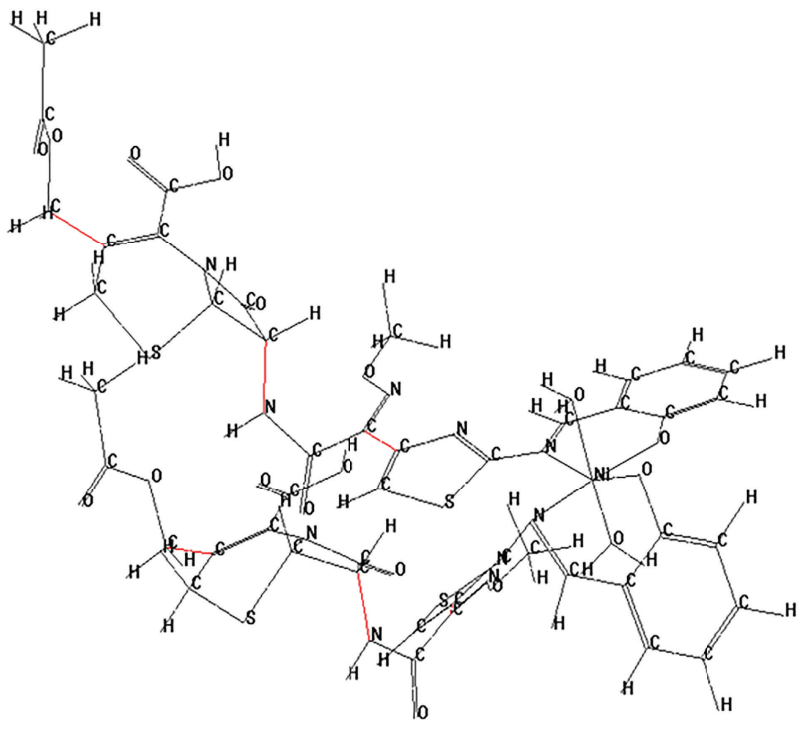

(a)

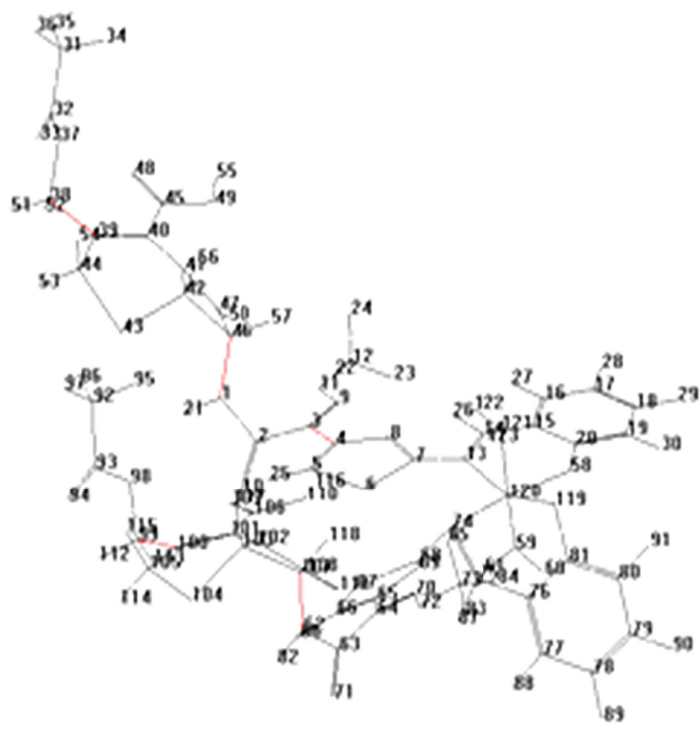

(b)

Figure 5: Molecular structure of the complex $\left[\mathrm{NiL}_{2}\left(\mathrm{H}_{2} \mathrm{O}\right)_{2}\right]$.

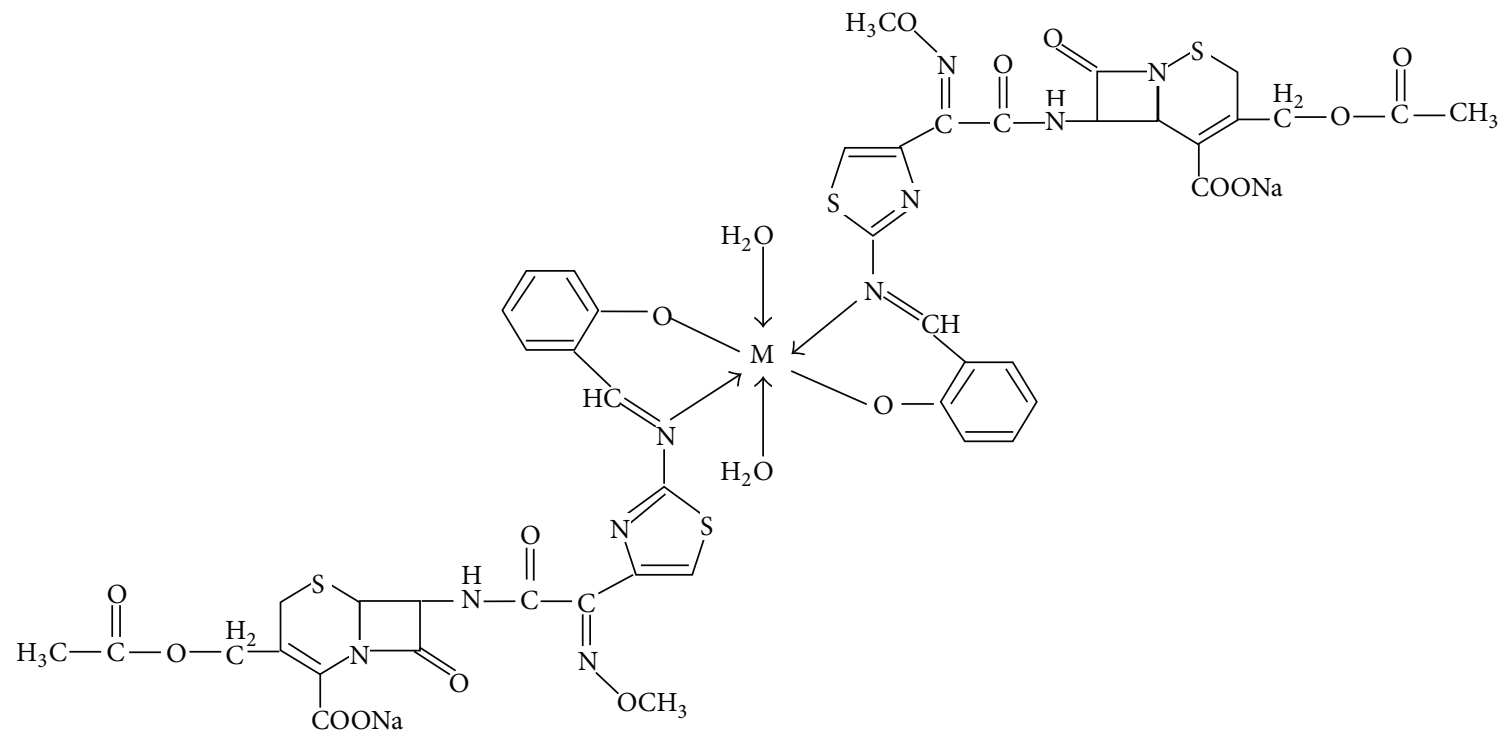

FIGURE 6: Proposed structures of the metal(II) complexes.

(iii) The values of the molecular shape descriptor OV (index oval), which expresses the ratio between the diameters of the smallest ellipsoid which contains a complex molecule, vary inversely proportionally to the molecular mass of the compounds.

On the basis of the above data, the proposed structures for the complexes $\left[\mathrm{ML}_{2}\left(\mathrm{H}_{2} \mathrm{O}\right)_{2}\right]$ where $\mathrm{L}=\mathrm{Schiff}$ base and $\mathrm{M}$ $=\mathrm{Co}(\mathrm{II}), \mathrm{Ni}(\mathrm{II}), \mathrm{Cu}(\mathrm{II})$, and $\mathrm{Zn}(\mathrm{II})$ are shown in Figure 6.

3.6. In Vitro Antimicrobial Discussion. The qualitative screening of the susceptibility spectra of various microbial strains to newly synthesized compounds showed that all tested compounds exhibited antimicrobial effect quantified by the occurrence of a growth inhibition zone (Table 7). For all tested complexes, the diameters of the inhibition zones were superior to those exhibited by DMSO alone and, also, those exhibited by the ligand and cefotaxime, suggesting that the antimicrobial activity of the obtained complexes is clearly superior to that of the ligand. The lowest antimicrobial spectrum was noticed for the $\mathrm{Ni}$ (II) complex, while the largest inhibitions zones were exhibited by the $\mathrm{Cu}$ (II) complex. The largest antimicrobial spectrum was obtained for $\mathrm{Co}$ (II) complex, which proved to be active against all tested microbial strains.

The results from the quantitative assay revealed that the tested compounds had a low inhibitory activity on bacterial growth. The absorbance values measured at $620 \mathrm{~nm}$ of the 


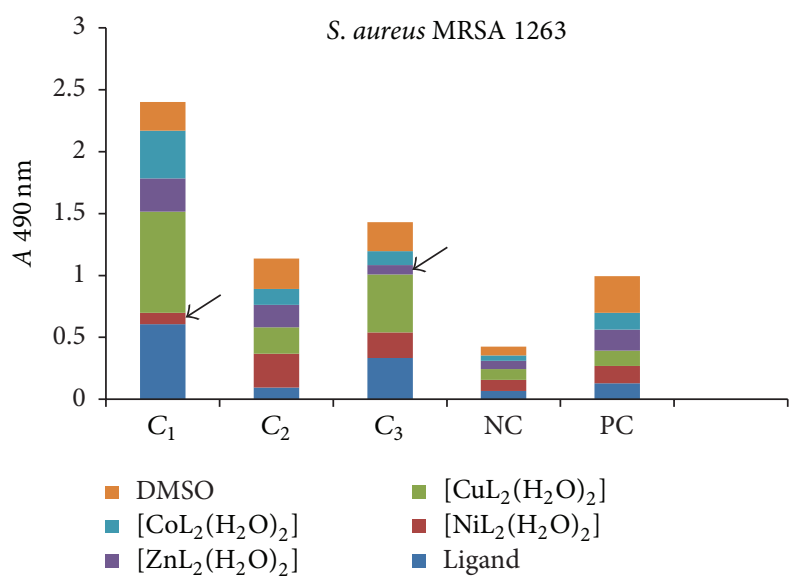

Figure 7: The intensity of $S$. aureus 1263 biofilm (quantified by $A 490 \mathrm{~nm}$ on $y$-axis) developed in the presence of three successive binary concentrations, that is, $1 \mathrm{mg} / \mathrm{mL}, 500 \mu \mathrm{g} / \mathrm{mL}$, and $250 \mu \mathrm{g} / \mathrm{mL}$ of the tested compounds (NC: negative, sterility control; PC: positive, growth control).

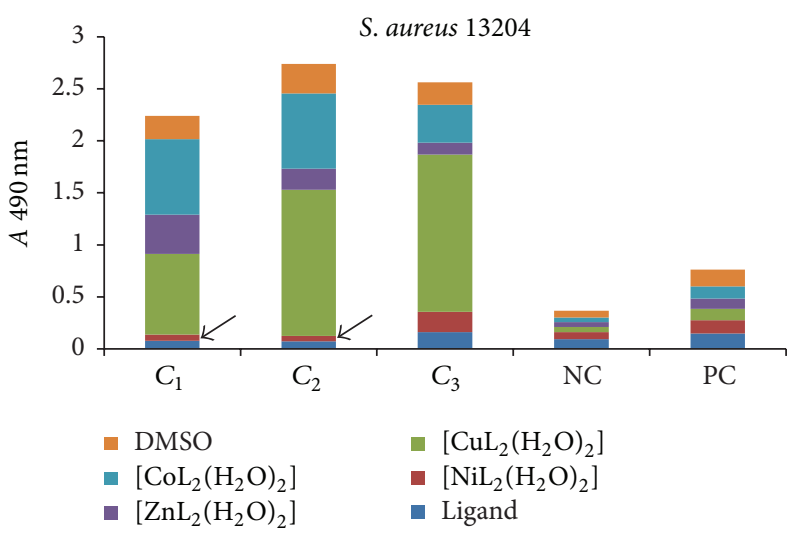

FIgURE 8: The intensity of $S$. aureus 13204 biofilm (quantified by A $490 \mathrm{~nm}$ on $y$-axis) developed in the presence of three successive binary concentrations, that is, $1 \mathrm{mg} / \mathrm{mL}, 500 \mu \mathrm{g} / \mathrm{mL}$ and $250 \mu \mathrm{g} / \mathrm{mL}$ of the tested compounds (NC: negative, sterility control; PC: positive, growth control).

bacteria grown in presence of the tested compounds were similar to those of the organic solvent used (DMSO) in the majority of cases, excepting $\mathrm{Ni}$ (II) complex for E. coli, $\mathrm{Co}(\mathrm{II})$ complex for E. coli, K. pneumoniae, and Cu(II) complex for $E$. coli, K. pneumoniae and S. aureus, this last complex proving to be the most efficient also in the quantitative assay (Table 8).

The influence of the tested compounds on the biofilm development on inert substrata was tested only on the microbial strains for which there have been registered good results in the previous assays, that is, S. aureus 1263, MRSA 13204, E. coli 13529, E. coli 13147, K. pneumoniae 13420, and K. pneumoniae 1204 . The obtained results showed that some of the compounds inhibited the ability of bacterial cells to colonize the inert substratum represented by the plastic wells, as revealed by the decreased values of $A 490 \mathrm{~nm}$, while some other compounds stimulated the biofilm development, as revealed by the increased values recorded for the $A 490 \mathrm{~nm}$, as compared with the positive control, represented by the microbial biofilm developed in the absence of the tested compounds (Figures 7-9).
Three successive concentrations of the obtained compounds, starting with $M I C$, that is, $1 \mathrm{mg} / \mathrm{mL}$ (noted $C_{1}$ ), followed by two subinhibitory concentrations, that is, $500 \mu \mathrm{g} / \mathrm{mL}$ (noted $C_{2}$ ) and $250 \mu \mathrm{g} / \mathrm{mL}\left(\right.$ noted $C_{3}$ ), were tested for their influence of the bacterial biofilm development. The antibiofilm activity of the tested compounds was generally lower than that exhibited by the ligand alone, excepting some few cases, detailed below.

In case of $S$. aureus strains, the complexes of $\mathrm{Ni}$ (II) (at concentrations ranging from $1 \mathrm{mg} / \mathrm{mL}$ to $500 \mu \mathrm{g} / \mathrm{mL}$ ), as well as of $\mathrm{Zn}$ (II) (at $250 \mu \mathrm{g} / \mathrm{mL}$ ), exhibited antibiofilm activity superior to that of the ligand (Figures 7 and 8).

In case of E. coli strains, the biofilm development was significantly inhibited by all tested concentrations of the ligand (Figures 9 and 10).

In case of K. pneumoniae strains (Figures 11 and 12), the antibiofilm activity of the tested compounds varied with the tested concentration. At the MIC corresponding concentration $\left(C_{1}\right.$ of $\left.1 \mathrm{mg} / \mathrm{mL}\right)$ only the complex of Ni exhibited anti-biofilm activity against one of the two tested strains 


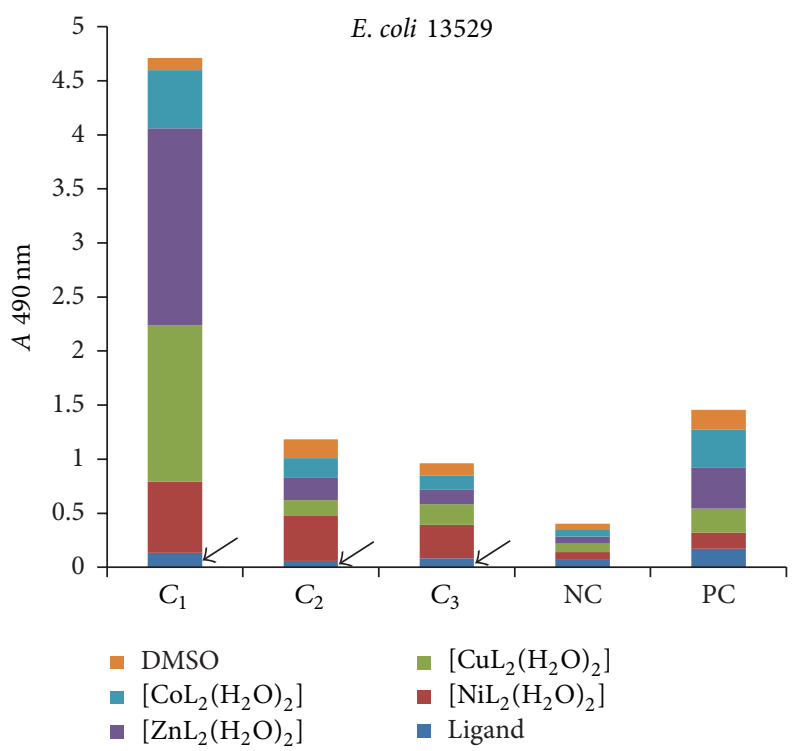

FIGURE 9: The intensity of E. coli 13529 biofilm (quantified by A $490 \mathrm{~nm}$ on $y$-axis) developed in the presence of three successive binary concentrations, that is, $1 \mathrm{mg} / \mathrm{mL}, 500 \mu \mathrm{g} / \mathrm{mL}$, and $250 \mu \mathrm{g} / \mathrm{mL}$ of the tested compounds (NC: negative, sterility control; PC: positive, growth control).

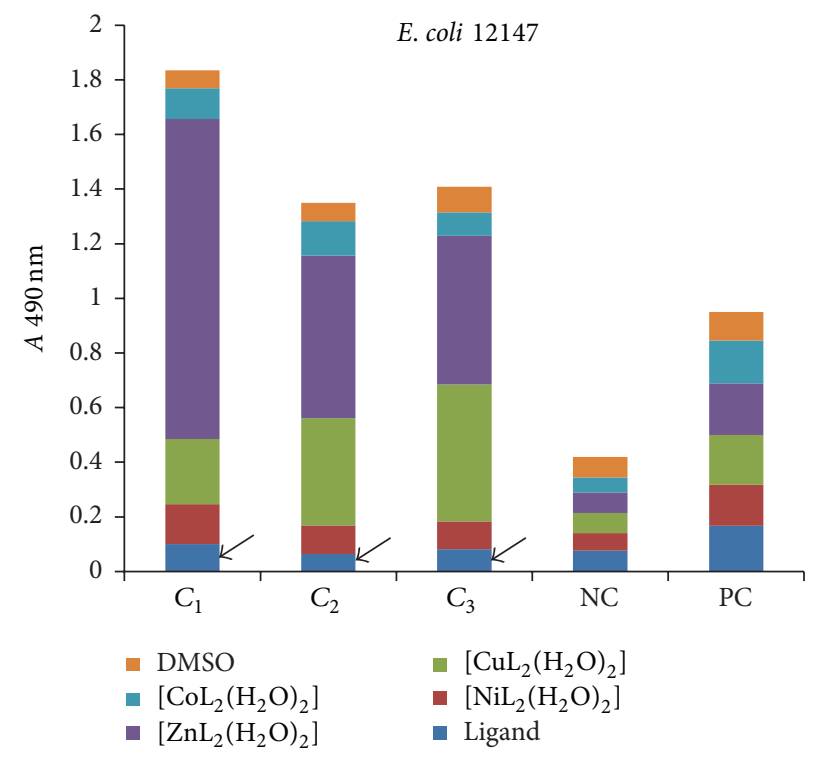

Figure 10: The intensity of E. coli 12147 biofilm (quantified by $A 490 \mathrm{~nm}$ on $y$-axis) developed in the presence of three successive binary concentrations, that is, $1 \mathrm{mg} / \mathrm{mL}, 500 \mu \mathrm{g} / \mathrm{mL}$, and $250 \mu \mathrm{g} / \mathrm{mL}$ of the tested compounds (NC: negative, sterility control; PC: positive, growth control).

(Figure 12). At the other two subinhibitory concentrations $\left(C_{2}\right.$ of $500 \mu \mathrm{g} / \mathrm{mL}$ and $C_{3}$ of $\left.250 \mu \mathrm{g} / \mathrm{mL}\right)$, the ligand, as well as the complexes of $\mathrm{Ni}(\mathrm{II}), \mathrm{Zn}$ (II) and $\mathrm{Co}(\mathrm{II})$ exhibited an antibiofilm activity.

These results are consistent with the fact that the growth in biofilms is accompanied by an increased tolerance up to 10 to 100 , or even more, 1000 to 4000 times higher than those established on planktonic/free cells, by the standard antibiotic susceptibility testing methods, evidently leading to clinical therapeutic failures of normal therapeutic doses of antibiotics. On the other side, the fact that, in some cases, the tested compounds exhibited antibiofilm activity at subinhibitory concentrations is suggesting their potential use as antibiofilm agents. The antibiofilm activity of the subinhibitory concentrations of the tested substances could be explained by the inhibition of bacterial metabolic pathways, implicated in the synthesis of different microbial components, including those implicated in different phases of the adherence and biofilm development processes. The fact that $K$. pneumoniae strains proved to be the most susceptible to 


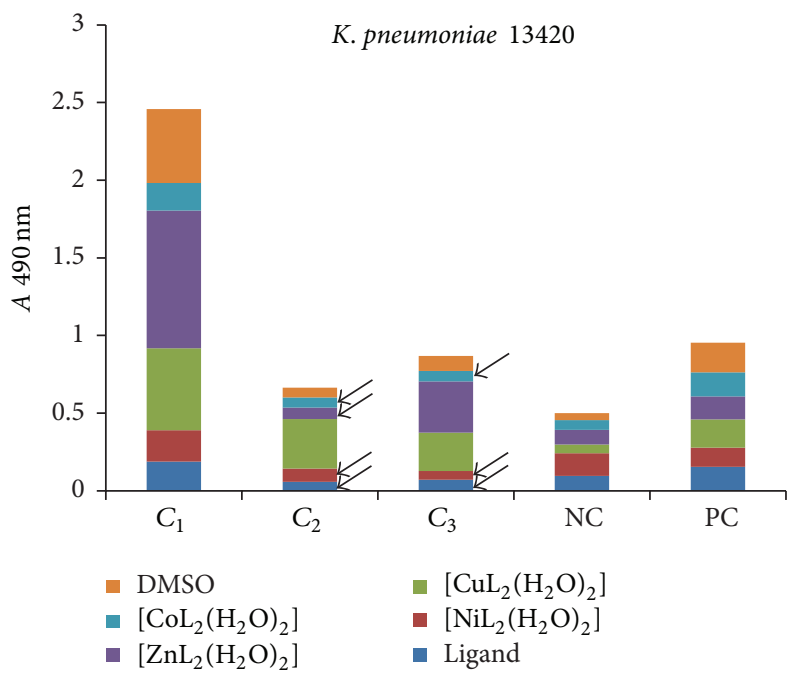

Figure 11: The intensity of K. pneumoniae 13420 biofilm (quantified by $A 490 \mathrm{~nm}$ on $y$-axis) developed in the presence of three successive binary concentrations, that is, $1 \mathrm{mg} / \mathrm{mL}, 500 \mu \mathrm{g} / \mathrm{mL}$, and $250 \mu \mathrm{g} / \mathrm{mL}$ of the tested compounds (NC: negative, sterility control; PC: positive, growth control).

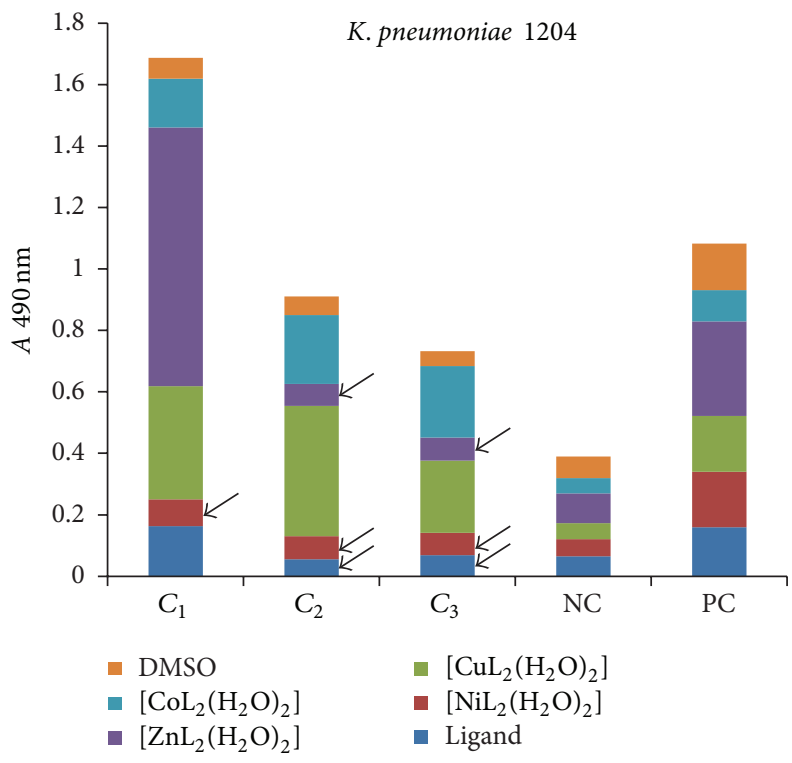

Figure 12: The intensity of K. pneumoniae 1204 biofilm (quantified by $A 490 \mathrm{~nm}$ on $y$-axis) developed in the presence of three successive binary concentrations, that is, $1 \mathrm{mg} / \mathrm{mL}, 500 \mu \mathrm{g} / \mathrm{mL}$, and $250 \mu \mathrm{g} / \mathrm{mL}$ of the tested compounds (NC: negative, sterility control; PC: positive, growth control).

the tested compounds concerning the ability to form biofilms on inert substrata could suggest that the tested compounds interfere with the synthesis of glycocalyx, the polysaccharidic substance which can form an organized structure called capsule, or an amorphous layer called slime, implicated in the formation of biofilms on inert surfaces.

Tweedy's chelation theory [40] offers an explanation for the increased antimicrobial activity of the metal complexes. In the chelated complex, the positive charge of the metal ion is partially shared with the donor atoms of the ligand and $\pi$ electron delocalization occurs over the whole chelate ring. In this way, the lipophilic character of the metal chelate is increasing and favouring its permeation through the lipoid layers of the bacterial membranes and blocking the metal binding sites in the microorganism.

\section{Conclusions}

Four metal(II) complexes with the Schiff base derived from cefotaxime with salicylaldehyde have been synthesized and characterised. Data from IR spectra concluded that the ligand behaves as a bidentate ligand coordinated in all the complexes. Electronic spectra and magnetic measurements indicate an octahedral geometry for $\mathrm{Co}(\mathrm{II}), \mathrm{Ni}(\mathrm{II})$, and $\mathrm{Zn}$ (II) 
TABle 4: Thermogravimetric data of $\mathrm{Co}(\mathrm{II}), \mathrm{Ni}(\mathrm{II})$, and $\mathrm{Cu}(\mathrm{II})$ complexes.

\begin{tabular}{|c|c|c|c|c|c|c|}
\hline Complex & Steps & $\begin{array}{c}\text { Thermal } \\
\text { effect }\end{array}$ & $\begin{array}{c}\text { Temperature } \\
\text { range }\left({ }^{\circ} \mathrm{C}\right)\end{array}$ & $\Delta m_{\exp } \%$ & $\Delta m_{\text {calc }} \%$ & Lost fragment \\
\hline \multirow{6}{*}{$\begin{array}{l}{\left[\mathrm{CoL}_{2}\left(\mathrm{H}_{2} \mathrm{O}\right)_{2}\right]} \\
\mathrm{CoC}_{46} \mathrm{H}_{42} \mathrm{~S}_{4} \mathrm{O}_{18} \mathrm{~N}_{10} \mathrm{Na}_{2}\end{array}$} & 1 & Endothermic & $70-117$ & 11.53 & 11.63 & $\mathrm{C}_{6} \mathrm{O}_{4} \mathrm{H}_{10}$ \\
\hline & 2 & Exothermic & 117-197 & 2.55 & 2.86 & $2 x \mathrm{H}_{2} \mathrm{O}$ \\
\hline & 3 & Exothermic & $197-294$ & 32.71 & 32.67 & $\mathrm{C}_{14} \mathrm{H}_{8} \mathrm{O}_{6} \mathrm{~S}_{2} \mathrm{~N}_{2} \mathrm{Na}_{2}$ \\
\hline & 4 & Endothermic & $294-453$ & 15.61 & 15.93 & $\mathrm{C}_{6} \mathrm{O}_{4} \mathrm{H}_{8} \mathrm{~N}_{4}$ \\
\hline & 5 & Exothermic & $453-595$ & 32.75 & 32.19 & degradation products + \\
\hline & & & & 4.58 & 4.69 & metallic oxide residue \\
\hline \multirow{6}{*}{$\begin{array}{l}{\left[\mathrm{NiL}_{2}\left(\mathrm{H}_{2} \mathrm{O}\right)_{2}\right]} \\
\mathrm{NiC}_{46} \mathrm{H}_{42} \mathrm{~S}_{4} \mathrm{O}_{18} \mathrm{~N}_{10} \mathrm{Na}_{2}\end{array}$} & 1 & Endothermic & $75-125$ & 11.73 & 11.63 & $\mathrm{C}_{6} \mathrm{O}_{4} \mathrm{H}_{10}$ \\
\hline & 2 & Exothermic & $125-205$ & 2.35 & 2.86 & $2 x \mathrm{H}_{2} \mathrm{O}$ \\
\hline & 3 & Exothermic & $205-302$ & 31.71 & 32.67 & $\mathrm{C}_{14} \mathrm{H}_{8} \mathrm{O}_{6} \mathrm{~S}_{2} \mathrm{~N}_{2} \mathrm{Na}_{2}$ \\
\hline & 4 & Endothermic & $302-460$ & 14.61 & 15.93 & $\mathrm{C}_{6} \mathrm{O}_{4} \mathrm{H}_{8} \mathrm{~N}_{4}$ \\
\hline & 5 & Exothermic & $460-602$ & 31.75 & 32.19 & degradation products + \\
\hline & & & & 4.78 & 4.72 & metallic oxide residue \\
\hline \multirow{6}{*}{$\begin{array}{l}{\left[\mathrm{CuL}_{2}\left(\mathrm{H}_{2} \mathrm{O}\right)_{2}\right]} \\
\mathrm{CuC}_{46} \mathrm{H}_{42} \mathrm{~S}_{4} \mathrm{O}_{18} \mathrm{~N}_{10} \mathrm{Na}_{2}\end{array}$} & 1 & Endothermic & $80-127$ & 11.79 & 11.59 & $\mathrm{C}_{6} \mathrm{O}_{4} \mathrm{H}_{10}$ \\
\hline & 2 & Exothermic & $127-207$ & 2.55 & 2.85 & $2 x \mathrm{H}_{2} \mathrm{O}$ \\
\hline & 3 & Exothermic & 207-304 & 32.71 & 32.55 & $\mathrm{C}_{14} \mathrm{H}_{8} \mathrm{O}_{6} \mathrm{~S}_{2} \mathrm{~N}_{2} \mathrm{Na}_{2}$ \\
\hline & 4 & Endothermic & $304-463$ & 15.61 & 15.87 & $\mathrm{C}_{6} \mathrm{O}_{4} \mathrm{H}_{8} \mathrm{~N}_{4}$ \\
\hline & 5 & Exothermic & $463-605$ & 32.15 & 32.07 & Degradation products + \\
\hline & & & & 4.98 & 5.04 & metallic oxide residue \\
\hline
\end{tabular}

TABLE 5: Structural descriptors of the studied compounds.

\begin{tabular}{lcccccc}
\hline \multirow{2}{*}{ Compound } & & \multicolumn{3}{c}{ Interatomic distances, $\AA$} \\
& $\mathrm{C}_{37}-\mathrm{C}_{38}$ & $\mathrm{C}_{38}-\mathrm{C}_{39}$ & $\mathrm{~N}_{1}-\mathrm{C}_{46}$ & $\mathrm{~N}_{1}-\mathrm{C}_{2}$ & $\mathrm{C}_{2}-\mathrm{C}_{3}$ & $\mathrm{C}_{3}-\mathrm{C}_{4}$ \\
\hline $\mathrm{L}$ & 1.4394 & 1.5182 & 1.4435 & 1.3865 & 1.5110 & 1.3466 \\
{$\left[\mathrm{NiL}_{2}\left(\mathrm{H}_{2} \mathrm{O}\right)_{2}\right]$} & 1.4093 & 1.5297 & 1.4520 & 1.3728 & 1.3602 & 1.3596 \\
{$\left[\mathrm{CuL}_{2}\left(\mathrm{H}_{2} \mathrm{O}\right)_{2}\right]$} & 1.4091 & 1.5298 & 1.4519 & 1.3727 & 1.3601 & 1.3412 \\
{$\left[\mathrm{ZnL}_{2}\left(\mathrm{H}_{2} \mathrm{O}\right)_{2}\right]$} & 1.4092 & 1.5299 & 1.4518 & 1.3726 & 1.3600 & 1.3568 \\
{$\left[\mathrm{CoL}_{2}\left(\mathrm{H}_{2} \mathrm{O}\right)_{2}\right]$} & 1.4092 & 1.5300 & 1.4519 & 1.3726 & 1.3601 & 1.3570 \\
\hline
\end{tabular}

TABLE 6: Structural descriptors of the studied compounds.

\begin{tabular}{|c|c|c|c|c|c|c|}
\hline Compound & $E(\mathrm{kcal} / \mathrm{mol})$ & $M(\mathrm{~g} / \mathrm{mol})$ & $\mu(\mathrm{D})$ & $\alpha\left(\AA^{3}\right)$ & $V\left(\AA^{3}\right)$ & $\mathrm{OV}$ \\
\hline $\mathrm{L}$ & 80.277 & 559.57 & 6.415 & 53.32 & 1361.67 & 1.6856 \\
\hline$\left[\mathrm{NiL}_{2}\left(\mathrm{H}_{2} \mathrm{O}\right)_{2}\right]$ & 277.223 & 1211.86 & 11.26 & 107.54 & 2603.47 & 1.9871 \\
\hline$\left[\mathrm{CuL}_{2}\left(\mathrm{H}_{2} \mathrm{O}\right)_{2}\right]$ & 287.481 & 1216.70 & 11.55 & 107.58 & 2605.22 & 1.9814 \\
\hline$\left[\mathrm{ZnL}_{2}\left(\mathrm{H}_{2} \mathrm{O}\right)_{2}\right]$ & 284.497 & 1218.52 & 11.69 & 107.59 & 2613.30 & 1.9800 \\
\hline$\left[\mathrm{CoL}_{2}\left(\mathrm{H}_{2} \mathrm{O}\right)_{2}\right]$ & 285.611 & 1212.08 & 11.56 & 107.56 & 2604.48 & 1.9815 \\
\hline
\end{tabular}

complexes and a tetragonal geometry for $\mathrm{Cu}$ (II) complex. The results from the biological activity demonstrated that the newly synthesized complexes could exhibit, in some cases, improved antimicrobial activity against both planktonic and biofilm embedded cells, superior to that of the ligand and the included antibiotic, so, they could be used for the development of novel antimicrobial materials or strategies for fighting medical biofilms pathogens frequently implicated in the etiology of biofilm associated chronic infection.

\section{Conflict of Interests}

The authors declare that there is no conflict of interests regarding the publication of this paper. 


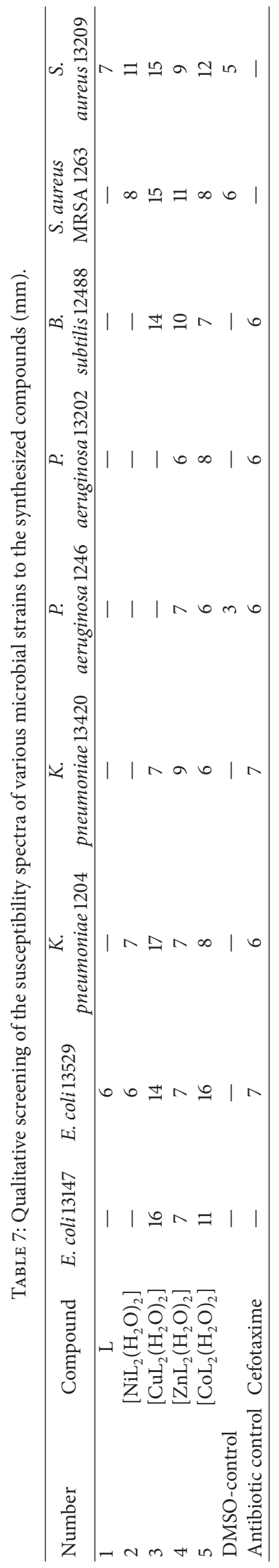




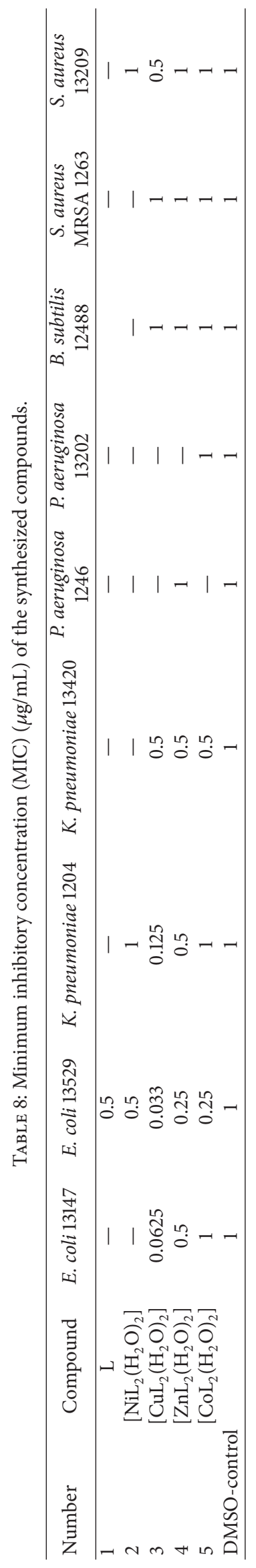




\section{References}

[1] N.-X. Chin, J.-W. Gu, W. Fang, and H. C. Neu, "In vitro activity and $\beta$-lactamase stability of GR69153, a new long-acting cephalosporin," Antimicrobial Agents and Chemotherapy, vol. 35, no. 2, pp. 259-266, 1991.

[2] K. P. Fu, B. D. Foleno, S. C. Lafredo, J. M. LoCoco, and D. M. Isaacson, "In vitro and in vivo antibacterial activities of FK037, a novel parenteral broad-spectrum cephalosporin," Antimicrobial Agents and Chemotherapy, vol. 37, no. 2, pp. 301-307, 1993.

[3] J. R. Anacona and J. Estacio, "Synthesis and antibacterial activity of cefixime metal complexes," Transition Metal Chemistry, vol. 31, no. 2, pp. 227-231, 2006.

[4] J. R. Anacona and J. J. Santaella, "In vitro, antibacterial activity of metal complexes containing a cephaclor derivative ligand," Latin American Journal of Pharmacy, vol. 32, no. 1, pp. 101-106, 2013.

[5] J. R. Anacona and M. Lopez, "Mixed-ligand nickel(II) complexes containing sulfathiazole and cephalosporin antibiotics synthesis, characterization, and antibacterial activity," International Journal of Inorganic Chemistry, vol. 2012, Article ID 106187, 8 pages, 2012.

[6] K. Singh, Y. Kumar, P. Puri, and G. Singh, "Spectroscopic, thermal, and antimicrobial studies of $\mathrm{Co}(\mathrm{II}), \mathrm{Ni}(\mathrm{II}), \mathrm{Cu}(\mathrm{II})$ and $\mathrm{Zn}$ (II) complexes derived from bidentate ligands containing $\mathrm{N}$ and S donor atoms," Bioinorganic Chemistry and Applications, vol. 2012, Article ID 729708, 9 pages, 2012.

[7] M. R. Karekal, V. Biradar, and M. B. H. Mathada, "Synthesis, characterization, antimicrobial, DNA cleavage, and antioxidant studies of some metal complexes derived from Schiff base containing indole and quinoline moieties," Bioinorganic Chemistry and Applications, vol. 2013, Article ID 315972, 16 pages, 2013.

[8] K. M. Khan, M. Khan, M. Ali et al., "Superoxide respiratory burst inhibitory activity of Bis-schiff bases of isatins," Journal of Chemical Society of Pakistan, vol. 35, no. 3, pp. 987-993, 2013.

[9] K. M. Khan, M. Taha, F. Rahim et al., "Acylhydrazide schiff bases: synthesis and antiglycation activity," Journal of Chemical Society of Pakistan, vol. 35, no. 3, pp. 929-937, 2013.

[10] Q. B. Li, L. W. Xue, W. C. Yang, and G. Q. Zhao, "Two new schiff base $\mathrm{Ni}^{\mathrm{II}}$ and $\mathrm{Cu}^{\mathrm{II}}$ complexes: synthesis and structures," Journal of the Chilian Chemical Society, vol. 58, no. 3, pp. 1880-1883, 2013.

[11] J. R. Anacona and C. Patiño, "Metalloantibiotics: synthesis and antibacterial activity of ceftazidime metal complexes," Journal of Coordination Chemistry, vol. 62, no. 4, pp. 613-621, 2009.

[12] A. E. Ali, "Synthesis, spectral, thermal and antimicrobial studies of some new tri metallic biologically active ceftriaxone complexes," Spectrochimica Acta A, vol. 78, no. 1, pp. 224-230, 2011.

[13] N. Raman, S. Sobha, and L. Mitu, "Design, synthesis, DNA binding ability, chemical nuclease activity and antimicrobial evaluation of $\mathrm{Cu}(\mathrm{II}), \mathrm{Co}(\mathrm{II}), \mathrm{Ni}(\mathrm{II})$ and $\mathrm{Zn}$ (II) metal complexes containing tridentate Schiff base," Journal of Saudi Chemical Society, vol. 17, no. 2, pp. 151-159, 2013.

[14] N. Sultana, M. S. Arayne, and M. Afzal, "Synthesis and antibacterial activity of cephradine metal complexes: part II complexes with cobalt, copper, zinc and cadmium," Pakistan Journal of Pharmaceutical Sciences, vol. 18, no. 1, pp. 36-42, 2005.

[15] A. Sakthivel, N. Raman, and L. Mitu, "DNA interaction studies of pyrazolone and diimine incorporated $\mathrm{Mn}(\mathrm{II}), \mathrm{Co}(\mathrm{II}), \mathrm{Ni}(\mathrm{II})$, $\mathrm{Cu}$ (II) and $\mathrm{Zn}(\mathrm{II})$ complexes: synthesis, spectroscopic characterization and antimicrobial study," Monatshefte Fur ChemieChemical Monthly, vol. 144, no. 5, pp. 605-620, 2013.
[16] Z. H. Chohan and C. T. Supuran, "In-vitro antibacterial and cytotoxic activity of cobalt (ii), copper (ii), nickel (ii) and zinc (ii) complexes of the antibiotic drug cephalothin (keflin)," Journal of Enzyme Inhibition and Medicinal Chemistry, vol. 20, no. 5, pp. 463-468, 2005.

[17] Z. H. Chohan, H. Pervez, K. M. Khan, A. Rauf, G. M. Maharvi, and C. T. Supuran, "Antifungal cobalt(II), copper(II), nickel(II) and zinc(II) complexes of furanyl-thiophenyl-, pyrrolyl-, salicylyl- and pyridyl-derived cephalexins," Journal of Enzyme Inhibition and Medicinal Chemistry, vol. 19, no. 1, pp. 85-90, 2004.

[18] M. S. Iqbal, I. H. Bukhari, and M. Arif, "Preparation, characterization and biological evaluation of copper(II) and zinc(II) complexes with Schiff bases derived from amoxicillin and cephalexin," Applied Organometallic Chemistry, vol. 19, no. 7, pp. 864-869, 2005.

[19] I. H. Bukhari, M. Arif, I. Akbar, and A. H. Khan, "Preparation, characterization and biological evaluation of Schiff base transition metal complexes with cephradine," Pakistan Journal of Biological Sciences, vol. 8, no. 4, pp. 614-617, 2005.

[20] M. Arif, M. M. R. Qurashi, and M. A. Shad, "Metal-based antibacterial agents: synthesis, characterization, and in vitro biological evaluation of cefixime-derived Schiff bases and their complexes with $\mathrm{Zn}(\mathrm{II}), \mathrm{Cu}(\mathrm{II}), \mathrm{Ni}(\mathrm{II})$, and $\mathrm{Co}(\mathrm{II})$," Journal of Coordination Chemistry, vol. 64, no. 11, pp. 1914-1930, 2011.

[21] S. Joshi, V. Pawar, and V. Uma, "Antibacterial and antioxidant properties of Mn (II), Co (II), Ni (II) and Zn (II) complex of Schiff base derived from cephalexin," Research Journal of Pharmaceutical, Biological and Chemical Sciences, vol. 2, no. 1, pp. 61-70, 2011.

[22] J. R. Anacona, J. Calvo, and O. A. Almanza, "Synthesis, spectroscopic, and magnetic studies of mono- and polynuclear Schiff base metal complexes containing salicylidene-cefotaxime ligand," International Journal of Inorganic Chemistry, vol. 2013, Article ID 108740, 7 pages, 2013.

[23] C. Limban and M. C. Chifiriuc, "Antibacterial activity of new dibenzoxepinone oximes with fluorine and trifluoromethyl group substituents," International Journal of Molecular Sciences, vol. 12, no. 10, pp. 6432-6444, 2011.

[24] C. Limban, A. V. Missir, I. C. Chirita et al., "Synthesis and antimicrobial properties of new 2-((4-ethylphenoxy)methyl) benzoylthioureas," Chemical Papers, vol. 65, no. 1, pp. 60-69, 2011.

[25] C. Limban, L. Marutescu, and M. C. Chifiriuc, "Synthesis, spectroscopic properties and antipathogenic activity of new thiourea derivatives," Molecules, vol. 16, no. 9, pp. 7593-7607, 2011.

[26] R. Olar, M. Badea, D. Marinescu et al., "Prospects for new antimicrobials based on N,N-dimethylbiguanide complexes as effective agents on both planktonic and adhered microbial strains," European Journal of Medicinal Chemistry, vol. 45, no. 7, pp. 2868-2875, 2010.

[27] G. M. Nitulescu, C. Draghici, M. C. Chifiriuc, L. Marutescu, C. Bleotu, and A. V. Missir, "Synthesis and antimicrobial screening of N-(1-methyl-1Hpyrazole- 4-carbonyl)-thiourea derivatives," Medicinal Chemistry Research, vol. 21, pp. 308-314, 2012.

[28] W. J. Geary, "The use of conductivity measurements in organic solvents for the characterisation of coordination compounds," Coordination Chemistry Reviews, vol. 7, no. 1, pp. 81-122, 1971.

[29] G. Brătulescu, Introduction in Organic Compounds Spectroscopy, Sitech, Craiova, Romania, 2009.

[30] K. Nakamoto, Infrared Spectra of Inorganic and Coordination Compounds, John Wiley \& Sons, New York, NY, USA, 4th edition, 1986. 
[31] G. Socrates, Infrared Characteristic Group Frequencies, John Wiley \& Sons, Chichester, UK, 1980.

[32] A. B. P. Lever, Inorganic Spectroscopy, Elsevier, Amsterdam, The Netherlands, 2nd edition, 1984.

[33] E. König, "The Nephelauxetic Effect," Structure and Bonding, vol. 9, pp. 175-212, 1971.

[34] F. A. Cotton, G. Williknson, C. A. Murillo, and M. Bochman, Advanced Inorganic Chemistry, John Wiley \& Sons, New York, NY, USA, 6th edition, 2003.

[35] B. N. Figgis, Introduction to Ligand Fields, John Wiley \& Sons, New York, NY, USA, 1976.

[36] N. Raman, R. Jeyamurugan, S. Sudharsan, K. Karuppasamy, and L. Mitu, "Metal based pharmacologically active agents: synthesis, structural elucidation, DNA interaction, in vitro antimicrobial and in vitro cytotoxic screening of Copper(II) and Zinc(II) complexes derived from amino acid based pyrazolone," Arabian Journal of Chemistry, vol. 6, no. 2, pp. 235-247, 2013.

[37] W. E. Estes, D. P. Gavel, W. E. Hatfield, and D. J. Hodgson, "Magnetic and structural characterization of dibromo- and dichlorobis(thiazole)copper(II)," Inorganic Chemistry, vol. 17, no. 6, pp. 1415-1421, 1978.

[38] J. Garcia, M. C. Molla, J. Borras, and E. Escriva, "Thermal study of mepirizol complexes with $\mathrm{Co}(\mathrm{II}), \mathrm{Ni}(\mathrm{II}), \mathrm{Cu}(\mathrm{II})$ and $\mathrm{Zn}(\mathrm{II})$," Thermochimica Acta, vol. 106, pp. 155-162, 1986.

[39] S. Funar-Timoftei, L. Crisan, S. Iliescu, G. Bandur, and E. Seclaman, "Conformational analysis of an arylazo phosphate dimer by molecular and quantum mechanics approaches," Chemical Bulletin of Politehnica Timisoara University, vol. 55, no. 69, pp. 2-10, 2010.

[40] N. Raman, A. Kulandaisamy, and K. Jeyasubramanian, "Synthesis, structural characterization, redox and antimicrobial studies of Schiff base copper(II), nickel(II), cobalt(II), manganese(II), zinc(II) and oxovanadium(II) complexes derived from benzil and 2-aminobenzyl alcohol," Polish Journal of Chemistry, vol. 76, no. 8, pp. 1085-1094, 2002. 

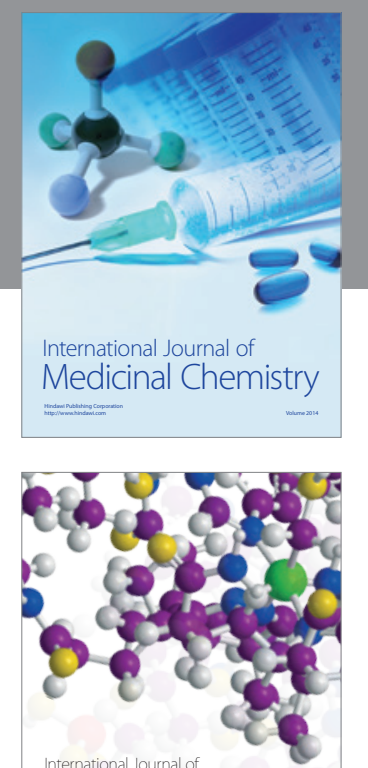

\section{Carbohydrate} Chemistry

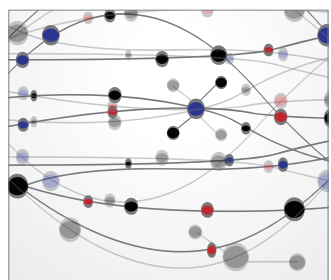

The Scientific World Journal
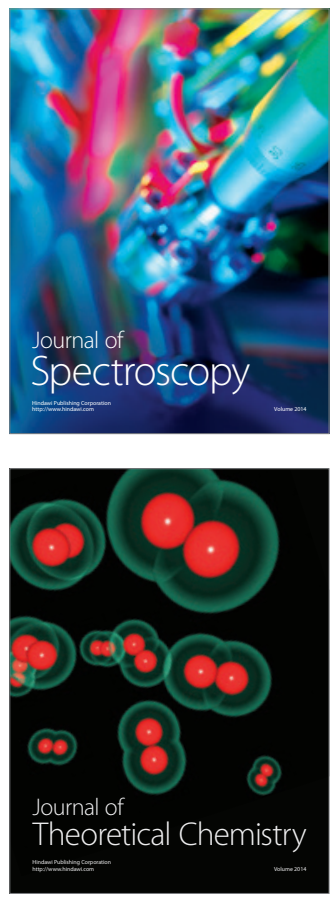
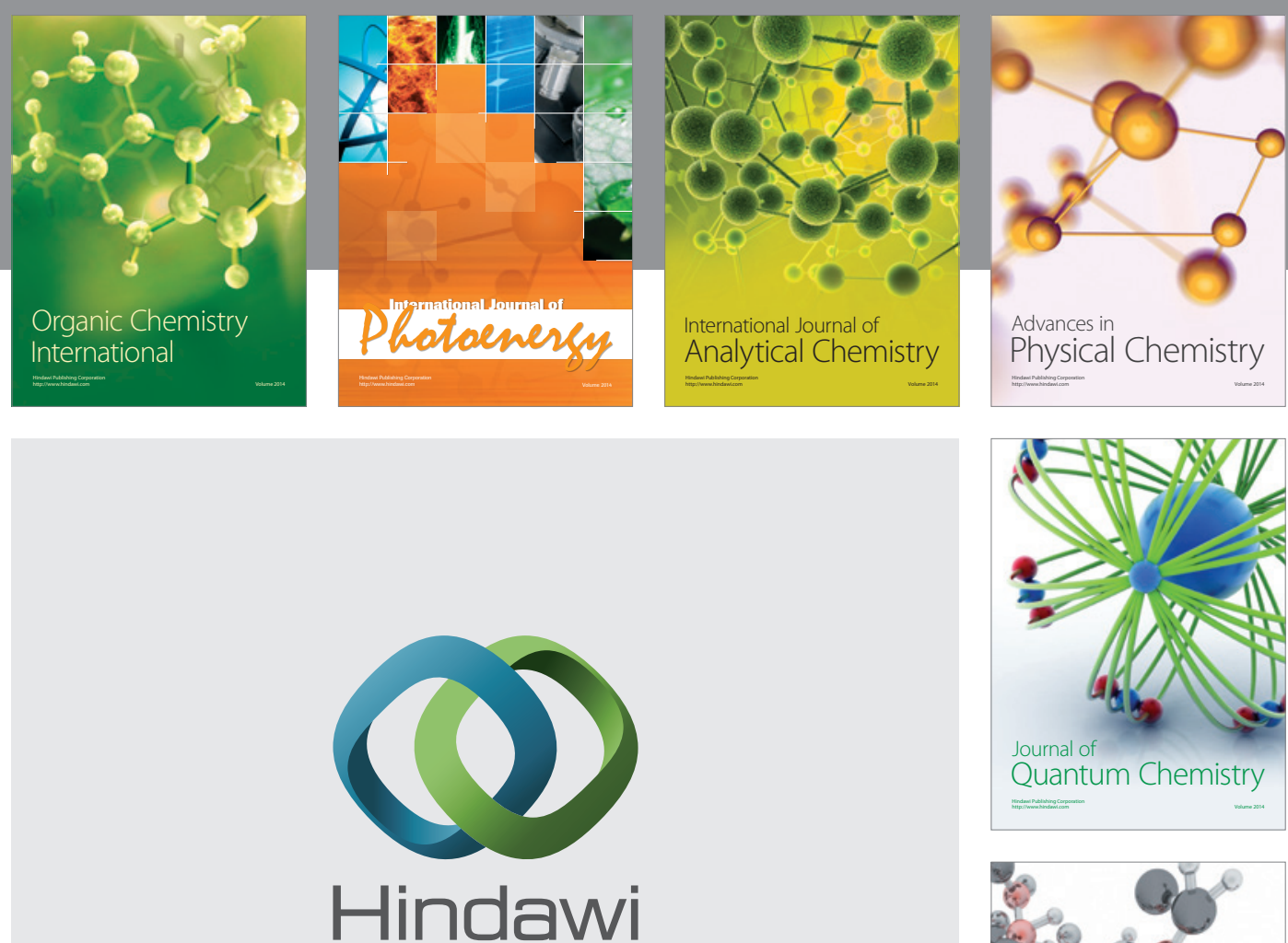

Submit your manuscripts at

http://www.hindawi.com

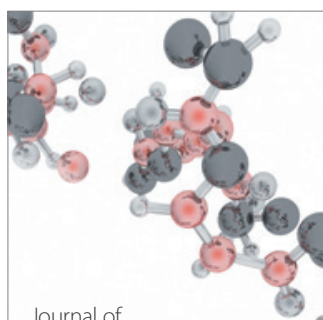

Analytical Methods

in Chemistry

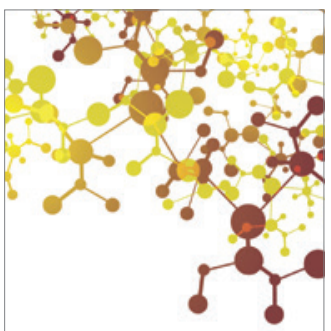

Journal of

Applied Chemistry

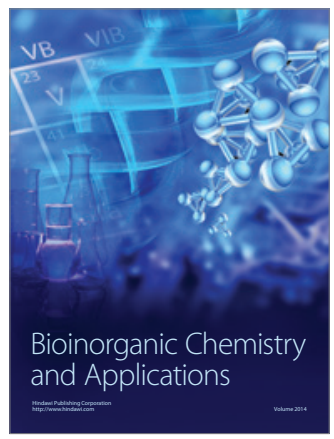

Inorganic Chemistry
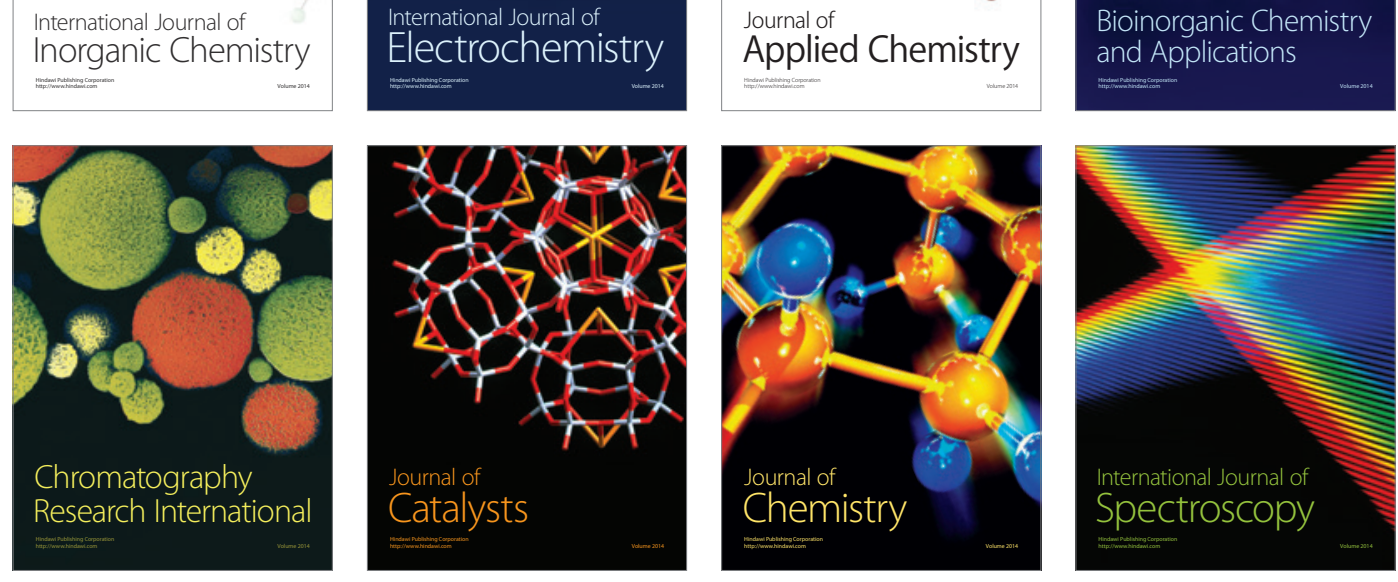